\title{
PUBLIC FINANCIAL MANAGEMENT SYSTEMS-FIJI KEY ELEMENTS FROM A FINANCIAL MANAGEMENT PERSPECTIVE
}




\section{PUBLIC FINANCIAL}

MANAGEMENT

SYSTEMS-FIJI

KEY ELEMENTS FROM A FINANCIAL

MANAGEMENT PERSPECTIVE

June 2017 
(C) (1)

(C) 2017 Asian Development Bank

6 ADB Avenue, Mandaluyong City, 1550 Metro Manila, Philippines

Tel +632632 4444; Fax +6326362444

www.adb.org

Some rights reserved. Published in 2017.

ISBN 978-92-9257-873-2 (Print), 978-92-9257-874-9 (e-ISBN)

Publication Stock No. TCS178906-2

DOI: http://dx.doi.org/10.22617/TCS178906-2

The views expressed in this publication are those of the authors and do not necessarily reflect the views and policies of the Asian Development Bank (ADB) or its Board of Governors or the governments they represent.

ADB does not guarantee the accuracy of the data included in this publication and accepts no responsibility for any consequence of their use. The mention of specific companies or products of manufacturers does not imply that they are endorsed or recommended by ADB in preference to others of a similar nature that are not mentioned.

By making any designation of or reference to a particular territory or geographic area, or by using the term "country" in this document, $A D B$ does not intend to make any judgments as to the legal or other status of any territory or area.

This work is available under the Creative Commons Attribution 3.0 IGO license (CC BY 3.0 IGO)

https://creativecommons.org/licenses/by/3.0/igo/. By using the content of this publication, you agree to be bound by the terms of this license. For attribution, translations, adaptations, and permissions, please read the provisions and terms of use at https://www.adb.org/terms-use\#openaccess

This CC license does not apply to non-ADB copyright materials in this publication. If the material is attributed to another source, please contact the copyright owner or publisher of that source for permission to reproduce it. ADB cannot be held liable for any claims that arise as a result of your use of the material.

Please contact pubsmarketing@adb.org if you have questions or comments with respect to content, or if you wish to obtain copyright permission for your intended use that does not fall within these terms, or for permission to use the ADB logo.

Notes:

In this publication, "\$” refers to US dollars.

ADB recognizes "China" as the People's Republic of China.

Corrigenda to ADB publications may be found at http://www.adb.org/publications/corrigenda 


\section{Contents}

Figures and Table $\quad \mathrm{v}$

Acknowledgments

Abbreviations viii

I. Introduction 1

II. Legal Framework 3

A. 2013 Constitution of the Republic of Fiji 3

B. Financial Management Act 2004

C. Finance Instructions 2010

D. Public Enterprise Act 1996

III. Key Players 8

A. Ministry of Economy 8

B. Office of the Auditor General $\quad 10$

C. Reserve Bank of Fiji 11

D. Asian Development Bank 11

$\begin{array}{lr}\text { IV. Budgeting } & 12\end{array}$

A. Budget Process 12

B. Budget Recording and Reporting 16

C. State Entities 18

$\begin{array}{ll}\text { V. Onlending Arrangements } & 20\end{array}$

VI. Foreign Exchange and Interest Rate Risks 21

VII. Funds Flow Arrangements $\quad 22$

A. Reimbursement Procedure $\quad 22$

B. Imprest Fund Procedure 23

C. Direct Payment Procedure 23

D. Commitment Procedure 24 
VIII.Accounting and Reporting

A. Accounting Standards

B. Cash Basis International Public Sector Accounting Standards

C. Accounting Systems

D. Responsible Units

E. Fiscal Year

F. Project Financial Statement Preparation

IX. Auditing Arrangements

A. Auditing Requirements

B. International Standards on Auditing

C. Shortcomings Identified through External Audits

X. Reporting and Monitoring

XI. Summary of Risks and Issues, and Proposed Mitigating Actions and Improvements

\section{Appendixes}

$1 \quad$ List of State Entities in Fiji 39

2 Fiji Institute of Accountants 40

3 Diagrams of Financial Management Information System Modules 43

4 Useful References and Suggested Readings 46 


\section{Figures and Table}

\section{Figures}

1 Ministry of Economy Organization Structure 8

2 Budget Preparation Steps and Timelines $\quad 13$

3 Phases of the Public Sector Investment Program 14

$4 \quad$ Capital Budgets and Project Budgets Channeled through the PSIP Process 15

5 Consolidated Fund Account and Consolidated Trust Fund Account 17

6 Funds Flow Arrangements for ADB Projects Using Reimbursement Procedure 22

$7 \quad$ Funds Flow Arrangements for ADB Projects Using Imprest Fund Procedure 23

$8 \quad$ Funds Flow Arrangements for ADB Projects Using Direct Payment Procedure 24

9 Funds Flow Arrangements for ADB Projects Using Commitment Procedure $\quad 25$

10 Fund Accounting Flowchart 30

Table

Common Issues, Problems, and Suggestions for Mitigating or Avoiding Risks 37 


\section{Acknowledgments}

The project team-Aman Trana, advisor, Operations Services and Financial

Management Department and head, financial management unit; Srinivasan Janardanam, principal financial management specialist; Anouj Mehta, principal financial management specialist; Abbas Kizilbash, senior financial management specialist; and Jessana Yanuario, senior financial management officer from the Operations Services and Financial Management Department of the Asian Development Bank (ADB) 一thank the following government officials who met with Eroni Vatuloka (consultant) and made valuable contributions to this report:

\section{Ministry of Economy}

David Kolitagane, deputy secretary, administration

Isikeli Voceduadua, acting deputy secretary, financial asset management unit

Sinate Mualaulau, acting deputy secretary, budget division

Necani Lagicere, chief accountant

Tuimasi Ulu, principal economist, budget division

Romeena Singh, principal economic planning officer, budget division

Pankaj Singh, acting director, debt and cash flow management unit

Letila Tuiyalani, principal accounts officer, debt and cash flow management unit Irimaia Rokosawa, acting director, financial management information systems (FMIS) Atunaisa Baleimatuku, acting principal accountant, FMIS

Buisena Conivavalagi, senior accountant, FMIS

\section{Fiji Roads Authority}

Sonal Gounder, acting chief financial officer

Ripon Baral, contract management engineer

\section{Water Authority of Fiji}

Opetaia Ravai, chief executive officer

Kee Fong, chief financial officer

Joana Kaloucava, capex accountant

Pita Waqanivalu, manager, finance

\section{Office of the Auditor General}

Atunaisa Nadakuitavuki, acting auditor general

Harik Raj, director, audit

Finau Nagera, director, audit

Sairusi Dukuno, director, audit 
Reserve Bank of Fiji

Barry Whiteside, governor

Arif Ali, deputy governor

Lorraine Seeto, chief manager, risk management and communications

Esala Masitabua, chief manager, financial markets.

University of the South Pacific

Tevita Banuve, project manager, ADB Project L2870/L3128 Higher Education in the Pacific Investment Program, Tranche 1

Nitendra Singh, deputy procurement manager

Salesh Kumar, procurement officer

Sarika Singh, management accountant

Lani Lewaseni, project office assistant

The assistance of the following ADB staff is likewise gratefully acknowledged: Grace King, senior project officer, financial management, Pacific Subregional Office; and Hayden

Everett, senior country specialist, Pacific Liaison and Coordination Office. 


\section{Abbreviations}

$\begin{array}{lll}\text { ADB } & - & \text { Asian Development Bank } \\ \text { CSA } & - & \text { commercial statutory authority } \\ \text { DeMPA } & - & \text { debt management performance assessment } \\ \text { FMA } & - & \text { Financial Management Act } \\ \text { FMIS } & - & \text { Financial Management Information System } \\ \text { FRUP } & - & \text { Fiji Road Upgrading Project } \\ \text { GCC } & - & \text { government commercial company } \\ \text { IAGG } & - & \text { Internal Audit and Good Governance (Division) } \\ \text { IFAC } & - & \text { International Federation of Accountants } \\ \text { IFRS } & - & \text { International Financial Reporting Standards } \\ \text { ISA } & - & \text { International Standards on Auditing } \\ \text { IPSAS } & - & \text { International Public Sector Accounting Standards } \\ \text { MIC } & - & \text { minority-owned company } \\ \text { MOC } & - & \text { majority-owned company } \\ \text { MOE } & - & \text { Ministry of Economy } \\ \text { OAG } & - & \text { Office of the Auditor General } \\ \text { PEA } & - & \text { Public Enterprise Act } \\ \text { PSIP } & - & \text { Public Sector Investment Program } \\ \text { RBF } & - & \text { Reserve Bank of Fiji } \\ \text { SOE } & - & \text { state-owned enterprise } \\ \text { TMA } & - & \text { trading and manufacturing account } \\ \text { WOG } & - & \text { whole of government }\end{array}$




\section{Introduction}

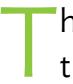

his paper is designed to support fiduciary risk assessments of projects financed by the Asian Development Bank (ADB). It provides information on Fiji's public financial management systems in the areas of funds flow, accounting, audit, and related matters that will be particularly useful to project officers who process and implement ADB-funded projects. The information in this paper may be leveraged when conducting financial management assessments of executing and implementing agencies, as well as in the design of disbursement, reporting and auditing, and other financial management arrangements.

Fijis financial management systems have changed significantly over the years as a result of reforms implemented by the Ministry of Economy (MOE). Two earlier public financial management reforms -in the late 1980s to the early 1990s, and in 1999-brought about changes that had a significant impact on the operations of government entities and the preparation of accounting information. Reforms in the late 1980s to the early $1990 \mathrm{~s}$ focused on improving public financial management and reporting, with the change from cash to accrual basis of accounting. In its Country Report of January 2003, the International Monetary Fund noted:

The early attempts were characterized by a "big bang" approach that sought to transplant best practices from Australia and New Zealand. Such efforts stretched Fijis limited administrative and accounting capacities. Lack of political will also limited progress and on occasion, led to an erosion of the efficacy of predecessor arrangements. ${ }^{1}$

The 1999 reforms introduced improvements in the civil service and public enterprises, and a new Financial Management Information System (FMIS), including new financial operational guidelines. The Public Service Act 1999, ${ }^{2}$ the Public Enterprise Act 1996, and the Public Finance Management Act 1999 were passed. However, the Public Finance Management Act 1999 was suspended ${ }^{3}$ by the government that took office in May 1999. ${ }^{4}$ The coup of 2000 further disrupted the progress of the reforms. The subsequent withdrawal of the new financial operational guidelines in 2000-2001 created implementation problems for accounting and administrative officers in the public service.

International Monetary Fund. 2003. Fiji: Selected Issues and Statistical Appendix. IMF Country Report. No. 03/9.

Washington, DC.p. 16.

2 A bill amending the Public Service Act 1999 is now in Parliament. See Government of the Republic of Fiji. Bill No. 16 of 2016: A Bill for an Act to Amend the Public Service Act 1999. Suva.

The Public Finance Management Act 1999 was replaced by the Financial Management Act (FMA) 2004.

See footnote 2 . 
Initiatives since the early 2000s have been more targeted. They have covered specific functions of the MOE and have included an upgrade of the FMIS called Masterpiece, as well as studies done by the World Bank in specific areas of the MOE, such as the Debt Management Performance Assessment (January 2014) ${ }^{5}$ and the Debt Management Reform Plan (August 2014). ${ }^{6}$ 


\section{Legal Framework}

\section{A. 2013 Constitution of the Republic of Fiji}

Cection 146 of the Fiji Constitution of 2013 states that all moneys must be dealt with $\checkmark$ and accounted for in accordance with the law, and with accounting principles generally accepted in the public sector. Section 127(7) further authorizes the permanent secretary of each ministry to appoint, remove, and institute disciplinary actions against all staff of the ministry, with the agreement of the minister responsible for the ministry. In addition, section 127 (8) gives the permanent secretary of each ministry, with the agreement of the minister responsible for the ministry, the authority to determine all matters pertaining to the employment of all staff in the ministry, including

(i) the terms and conditions of employment;

(ii) the qualification requirements for appointment and the appointment process to be followed, which must be open, transparent, and competitive selection based on merit;

(iii) the salaries, benefits, and allowances payable, in accordance with the ministry's budget as approved by Parliament; and

(iv) the total establishment, or the total number of staff that are to be required, in accordance with the budget as approved by Parliament.

The MOE's Financial Management Act (FMA) 2004 and the Finance Instructions 2010 contain the principle and standards related to Fijis financial management systems.

\section{B. Financial Management Act 2004}

FMA 2004 sets down the following principles of responsible financial management:

(i) managing finances responsibly and transparently over the medium term;

(ii) managing revenues and expenditure in such a way as to achieve prudent levels of debt;

(iii) ensuring value for money in the use of money and resources;

(iv) managing contingent liabilities prudently; and

(v) reporting transparently in accordance with relevant accounting and statistical standards. ${ }^{7}$ 
The FMA entrusts the minister of economy with the task of managing the financial affairs of the government with due regard to the principles of responsible financial management. ${ }^{8}$ It also directs the responsible authority of a state entity to manage the financial affairs of the entity in accordance with the requirements of the Act with due regard to the principles of responsible financial management. ${ }^{9}$

The chief executive officers (CEOs) or permanent secretaries and other responsible authorities manage the affairs of their respective ministries and departments, specifically the effective and economic management of the entity, the maintenance of an effective system of internal control, the preparation of annual reports, and other responsibilities stipulated in section 28 of the FMA 2004. The CEOs of budget sector agencies are responsible for providing an annual corporate plan, administering the agency's appropriations, and issuing a finance manual for the agency, in addition to the aforementioned functions.

The FMA also has provisions for budget sector and off-budget sector agencies or entities. The commercial entities are listed in Appendix 1. The project implementation units of ADBfunded projects fall under budget sector entities or agencies (entities or agencies provided with annual budgets by the government), ${ }^{10}$ or under off-budget entities or agencies (entities or agencies that retain revenue collected for operating and capital expenditures). ${ }^{11}$

The FMA states that the finance instructions may make provisions for the adoption of accrual accounting principles, policies, and procedures for either entire government reporting or budget sector agency reporting, or both. ${ }^{2}$ It adds that these accrual accounting policies may apply differently to different aspects of accounting and to different budget sector agencies; and may be adopted in stages given the varying capabilities of the agencies to effectively adopt accrual accounting.

The Act further notes that, within 9 months after the end of the financial year, the minister of economy must table in the House of Representatives the whole of government (WOG) annual report, which will include the WOG financial statements, the annual appropriation statement, and the annual budget statement. ${ }^{13}$ The WOG financial statements shall comprise

(i) a statement of financial position,

(ii) a statement of financial performance,

(iii) a statement of changes in net assets,

(iv) a cash flow statement, and

(v) notes on significant accounting policies.

Government of the Republic of Fiji. 2004. Financial Management Act. Section 6. Suva. Government of the Republic of Fiji. 2004. Financial Management Act. Section 7. Suva.

10 Government of the Republic of Fiji. 2004. Financial Management Act. Section 2. Suva. A budget sector agency in relation to a financial year refers to a state entity that administers an appropriation for that year under an appropriation act.

11 Government of the Republic of Fiji. 2004. Financial Management Act. Section 2. Suva. An off-budget state entity is any state entity that is not a budget sector agency. A state entity is a department, a parliamentary body, a statutory authority, or a government company, including its associated entities.

12 Government of the Republic of Fiji. 2004. Financial Management Act. Section 26. Suva.

13 Government of the Republic of Fiji. 2004. Financial Management Act. Section 45. Suva. 
These statements are to be prepared in accordance with the international accounting standards as found in FMA 2004. The Act further provides that, where reliable accrual information is not available, the following statements shall compose the WOG financial statements:

(i) one or more statements of receipts and payments;

(ii) a statement of assets and liabilities, including details of cash balances, investments, sinking funds, and borrowings; and

(iii) a statement of contingent liabilities. ${ }^{14}$

The annual appropriation statement must show

(i) the actual revenue and expenditure, surplus, or deficit for the financial year;

(ii) the corresponding revenue estimates and appropriations for the financial year; and

(iii) details of reportable authorizations. ${ }^{15}$

The annual budget statement must show

(i) the revenue, expenditure, and surplus or deficit for each of the 2 previous years;

(ii) the estimated revenue, expenditure, and surplus or deficit for the financial year;

(iii) the projected revenue, expenditure, and surplus or deficit, for the next 2 financial years;

(iv) a disaggregation of revenue, estimated revenue, and projected revenue by economic type;

(v) a disaggregation of expenditure, estimated expenditure, and projected expenditure by economic type; and

(vi) a statement comparing, for each type of financial target or limit specified in the most recently tabled strategic policy statement under section 12: (a) that target or limit; (b) any revisions specified in the budget statement or statements under section 13 of that target limit; (c) the actual results. ${ }^{16}$

The Act further provides for the WOG financial statements and the annual appropriation statement to be signed by the chief executive officer of the Ministry of Finance and audited by the auditor general and be accompanied by his/her audit opinion.

The annual report of a government budget sector agency must

(i) demonstrate the agency's performance during the year in terms of its outputs and contributions to outcomes,

(ii) include the agency's annual financial statements, and

(iii) include other information required by the finance instructions. ${ }^{17}$ 
The annual financial statements of a budget sector entity or agency must be prepared in accordance with the Finance Instructions, signed by the chief executive officer of the agency, and audited by the auditor general.

The annual reports of an off-budget state entity or agency, including its annual financial statements, must be prepared and tabled in the House of Representatives in the manner required under the Finance Instructions, which include the entity's annual financial statements. ${ }^{18}$ The financial statements shall be prepared under the relevant legislation and the Finance Instructions, signed by the chairperson (of the board) and chief executive officer, and audited by the auditor general. ${ }^{19}$

\section{Finance Instructions 2010}

The Finance Instructions 2010 are regulations created under the FMA which set the minimum standards for the financial management of government agencies. The Finance Instructions cover the elements of financial statements, namely, expenditure, revenue, assets, and liabilities. The instructions also provide for other important aspects of financial management, including losses, trust money, internal controls, surcharges, reporting, and internal audit.

\section{Internal Controls}

Section 59 of the Finance Instructions provides that each agency must have in place a cost-effective system of internal controls to safeguard money and property against loss, avoid or detect accounting errors, and avoid getting unfavorable audit reports. The agency accounting head is responsible to the permanent secretary for instituting such a system within the agency. The accounting head has a very important role to play in ensuring effective internal controls:

(i) Section 60 requires the accounting head to produce a signed and dated monthly report to the permanent secretary detailing the extent of compliance with all the necessary reconciliations and checks, and the current status of any unresolved external and internal audit issues.

(ii) Section 61 requires the accounting head to ensure that all officers of the agency who are responsible for particular controls are aware of their responsibilities.

\section{Reporting}

The permanent secretary will receive at the end of each month a management report on service delivery performance, financial performance, trading and manufacturing account $(T M A)^{20}$ performance, and other significant issues needing the attention of the permanent

\footnotetext{
Government of the Republic of Fiji. 2004. Financial Management Act. Section 51. Suva.

See footnote 18.

A trading and manufacturing account is a type of account established under part 5 of the Finance Instructions 2010 to cover the semicommercial operations of a government department. For example, the printing department under the MOE operates a TMA for the production and sale of government reports and documents it produces for the government and the public at large, as well as for the manufacture and sale of school stationery.
} 
secretary (Finance Instructions, section 67). The permanent secretary is required to submit a report to the relevant minister on the financial operations of the agency compared with the budget, and the progress of the implementation of output specified in the annual corporate plans (Finance Instructions, section 68).

In addition, the agency must prepare an annual report to its minister by 30 May of the following year (Finance Instructions, section 69), which shall at least contain the following: a review of major issues by the permanent secretary and an overview of performance and activities, an agency overview, a report on performance, and a report on how resources were managed (Finance Instructions, section 70). The audited financial statements of the agency, signed by the permanent secretary, shall be part of the annual report. These shall comprise a statement of receipts and expenditures, a profit and loss statement, a statement of assets and liabilities for each TMA (where applicable), notes to the statement of assets and liabilities, a statement of losses, and a trust account statement of receipts and payments (where applicable) (Finance Instructions, section 71).

\section{Inconsistency among the 2013 Constitution, the Financial Management Act 2004, and the Finance Instructions 2010}

The powers devolved to the permanent secretary under sections 127(7) and 127(8) of the 2013 Constitution have yet to be incorporated into the FMA 2004 and the Finance Instructions 2010. These inconsistencies in the legal framework must be resolved. Accordingly, the government reviewed the FMA in 2016, and will review the Finance Instructions and relevant legislation to ensure consistency with the act.

\section{Public Enterprise Act 1996}

The Public Enterprise Act (PEA) 1996 defines the governance arrangements and operations of Fiji's state-owned enterprises (SOEs). These comprise government commercial companies (GCCs) and commercial statutory authorities (CSAs). A GCC is a government company formed and registered under Fiji's Companies Act, and declared a company by the Ministry of Public Enterprises under the PEA. A CSA is a statutory authority formed under a statute, and declared a CSA by the Ministry of Public Enterprises in accordance with the PEA. 


\section{Key Players}

\section{A. Ministry of Economy}

The MOE is responsible for promoting sound financial resource management practices among various government agencies, and sound economic management of the national economy consistent with macroeconomic targets for long-term development. The government announced the renaming of the former Ministry of Finance, to take effect on 1 August 2016, when tabling the 2016-2017 Appropriation Bill on 22 June 2016. The change in name was seen to reflect the ministry's more comprehensive approach to ensuring the country's economic sustainability, and to align with civil service reform.

The Ministry that manages robust economy, the Ministry of Finance, will change its name to the Ministry of Economy come 1 August, to reflect the more comprehensive approach to our economic wellbeing and which sits with our reform, to create a modern Civil Service. ${ }^{21}$

The organization structure of the MOE is provided in Figure 1.

\section{Figure 1: Ministry of Economy Organization Structure}

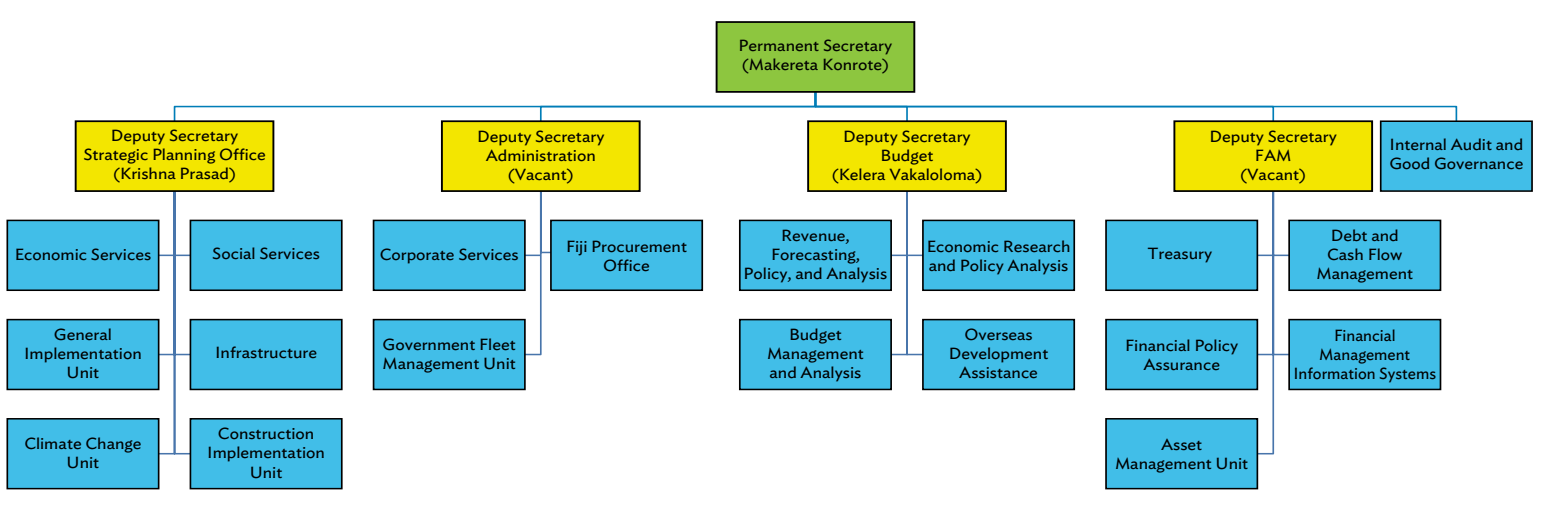

FAM = financial and asset management division.

Source: Ministry of Economy. 
The roles of the various divisions and units of the MOE are as follows:

\section{Administration Division}

The administration division provides ministerial and executive support to the permanent secretary and the minister of finance to ensure the successful implementation of programs in line with the ministry's corporate objectives. ${ }^{22}$ The activities are undertaken by the executive support group; the personnel section; and the post processing, vehicle control, office services, and training units.

\section{Budget Division}

The budget division is responsible for the efficient, effective, and equitable allocation of scarce resources through the government's budgetary system, including the formulation, implementation, and monitoring of the annual budget and budget policies with a view to promoting economic growth. ${ }^{23}$ The four units of the division are as follows:

(i) revenue policy, forecasting, and analysis unit, responsible for providing sound economic and financial advice regarding fiscal and macroeconomic issues;

(ii) budget policy, monitoring, and analysis unit, which monitors and reports on the effectiveness of key budget policies and programs;

(iii) overseas development assistance unit, which manages, coordinates, and administers, and provides reports on, foreign aid, including that provided by ADB; and

(iv) expenditure management and analysis unit, which is responsible for budgeting, the release of key funds, and the monitoring of expenditures.

\section{Financial and Asset Management Division}

The financial and asset management division is responsible for managing the finances and the financial assets of government. The division comprises asset management, debt and cash flow management, FMIS, financial policy assurance, and treasury units. ${ }^{24}$

(i) The asset management unit monitors and provides advice to government ministries and departments that operate trading and manufacturing accounts. These are sections or units of departments that operate on a semicommercial basis, manufacturing and selling goods to other departments and to the public (see footnote 20).

(ii) The debt and cash flow management unit raises, manages, and retires debt at the lowest possible long-term cost and at an acceptable degree of risk.

(iii) The FMIS unit facilitates and administers the accounting systems and processes of the central government and the various government ministries and departments.

(iv) The financial policy assurance unit provides policy advice and assurance on financial accounting policy matters to the permanent secretary, the minister of economy, and other stakeholders. 
(v) Treasury Unit-responsible for government accounting, including formulation, implementation, and monitoring of accounting policies so that they are consistent with generally accepted accounting principles of Fiji; and the preparation of WOG financial statements and reports. One of the roles of the unit is managing the government's payment system and maintaining sufficient cash in bank accounts for spending by ministries and departments. The treasury unit also maintains a cash buffer to handle unexpected outflows, provides accounting and financial advice to ministries and departments, and represents the government on the board of selected SOEs as well as at Public Accounts Committee meetings.

\section{Internal Audit and Good Governance Division}

The internal audit and good governance (IAGG) division ${ }^{25}$ is responsible for internal audit, surcharge, ${ }^{26}$ financial control reviews, special investigation, and the implementation of the new TeamMate audit software. It is also responsible for internal audits and good governance in ministries that conduct their own internal audits (e.g., health, infrastructure and transport, education, and agriculture). ${ }^{27}$

\section{Strategic Planning Office}

The strategic planning office ensures the better coordination of national development efforts through the effective formulation, implementation, and monitoring of government initiatives and forward-looking socioeconomic planning, statistical analysis, and advice. The division also includes two new units: the climate change and construction implementation units.

\section{Procurement Division}

The Procurement Division ${ }^{28}$ is established under Section 4 of the Fiji Procurement Regulations 2010 and began operating on 1 August 2010. It functions mainly to regulate and administer the procurement of goods, services, and works for the government. ${ }^{29}$

\section{B. Office of the Auditor General}

Section 152(1) of the 2013 Constitution states that, at least once every year, the auditor general shall inspect, audit, and report to Parliament on the public accounts of the state, the control of public money (including government projects) and public property of the state, and all transactions with or concerning the public moneys or public property of the state. The 2013 Constitution further provides for the Auditor General to state in the opinion that transactions with or concerning the public money or public property of the state have been legally authorized, and expenditure has been applied to the purpose for which it was

\footnotetext{
Ministry of Economy. www.economy.gov.fj

Surcharge is the imposition of a financial penalty on civil servants for actions that result in a loss to the government. These actions may include damage to or loss of government vehicles or other government assets, loss of cash or inventories, unauthorized expenditures, and disregard of the Finance Instructions 2010.

Government of the Republic of Fiji. 2004. Financial Management Act. Section 72(1). Suva.

Ministry of Economy. www.economy.gov.fj

Ministry of Economy. www.economy.gov.fj
} 
authorized. The Office of the Auditor General (OAG) is further empowered by the Audit (Amendment) Act 2006 to inspect, audit, and report to Parliament on the public accounts of the state, the control of public money, and public property of the state. This includes the audit of projects. The reports of the auditor general, after being tabled in Parliament, are scrutinized by the Standing Committee on Public Accounts, commonly called the Public Accounts Committee. ${ }^{30}$ The committee examines the accounts of the Government of Fiji for each financial year, reports of the auditor general, and any other matters relating to the expenditures of the Government of Fiji or any directly or indirectly related body or activity that the committee sees fit to review.

\section{Reserve Bank of Fiji}

The Reserve Bank of Fiji regulates the issue of currency and the supply, availability, and international exchange of money, and promotes sound financial structure and monetary stability, among other responsibilities.

\section{Asian Development Bank}

\section{Controller's Department, Loan Administration Division}

The Controller's Department of ADB is responsible for the administration of all loans, grants, and technical assistance disbursements, including the maintenance of the related accounting policy and systems, and prepares financial reports as well as billing and collection of loan service payments.

\section{Pacific Subregional Office}

ADB's Pacific Subregional Office undertakes strategic planning, country programming, and economic sector work, overall portfolio management, and project administration of selected projects; supports the development of knowledge products; and conducts capacity-building and regional cooperation activities. The Pacific Subregional Office is responsible for the following countries in the Pacific region besides Fiji: Cook Islands, Kiribati, Samoa, Tonga, and Tuvalu.

30 Government of the Republic of Fiji. 2014. The Standing Orders of the Parliament of the Republic of Fiji. Chapter 10. Suva. 


\section{Budgeting}

\section{A. Budget Process}

ection 13 of the FMA provides that before the start of each financial year, the minister of economy must table in Parliament the budget papers for the annual budget for the next financial year. The budget papers comprise a bill for an annual appropriations act, budget estimates, a statement of estimated budget results, a summary of outcomes, any new policy actions, economic and financial forecasts, major assumptions, and estimated revenue to be retained by a state entity. The budget estimates and associated statements are prepared on the basis of internationally accepted standards, and include estimates where specific approval by the minister of economy is required.

Budget preparation at agency level is guided by MOE Finance Circular 17/2013 of 19 July 2013, which contains information about the budget strategy and the baseline budget. The circular draws on the Cabinet-approved budget strategy, which covers global and domestic prospects, and a physical strategy for the medium term, as well as specifying fiscal policy measures, including revenue, expenditure, and debt policies and recommended measures. The proposed agency allocation endorsed by the Cabinet is conveyed to each agency, which must prioritize programs and activities within the approved fiscal space. The agencies are required to align their programs with the government's priorities and reduce unnecessary spending and waste. The budget timelines ${ }^{31}$ for the calendar financial year are provided in Figure 2.

The MOE sets the budget baselines after considering the following:

(i) the expenditure performance over the past year, to determine whether the provisions can continue at the same level or should be revised downward;

(ii) the strategy used in budgeting for salaries and wages;

(iii) cost-cutting measures and whether they have all been implemented;

(iv) the accurate level of expenditures, given the budget transfers;

(v) one-off projects that have been removed from the budget; and

(vi) operating grants, taking into account current as well as past performance. ${ }^{32}$ 


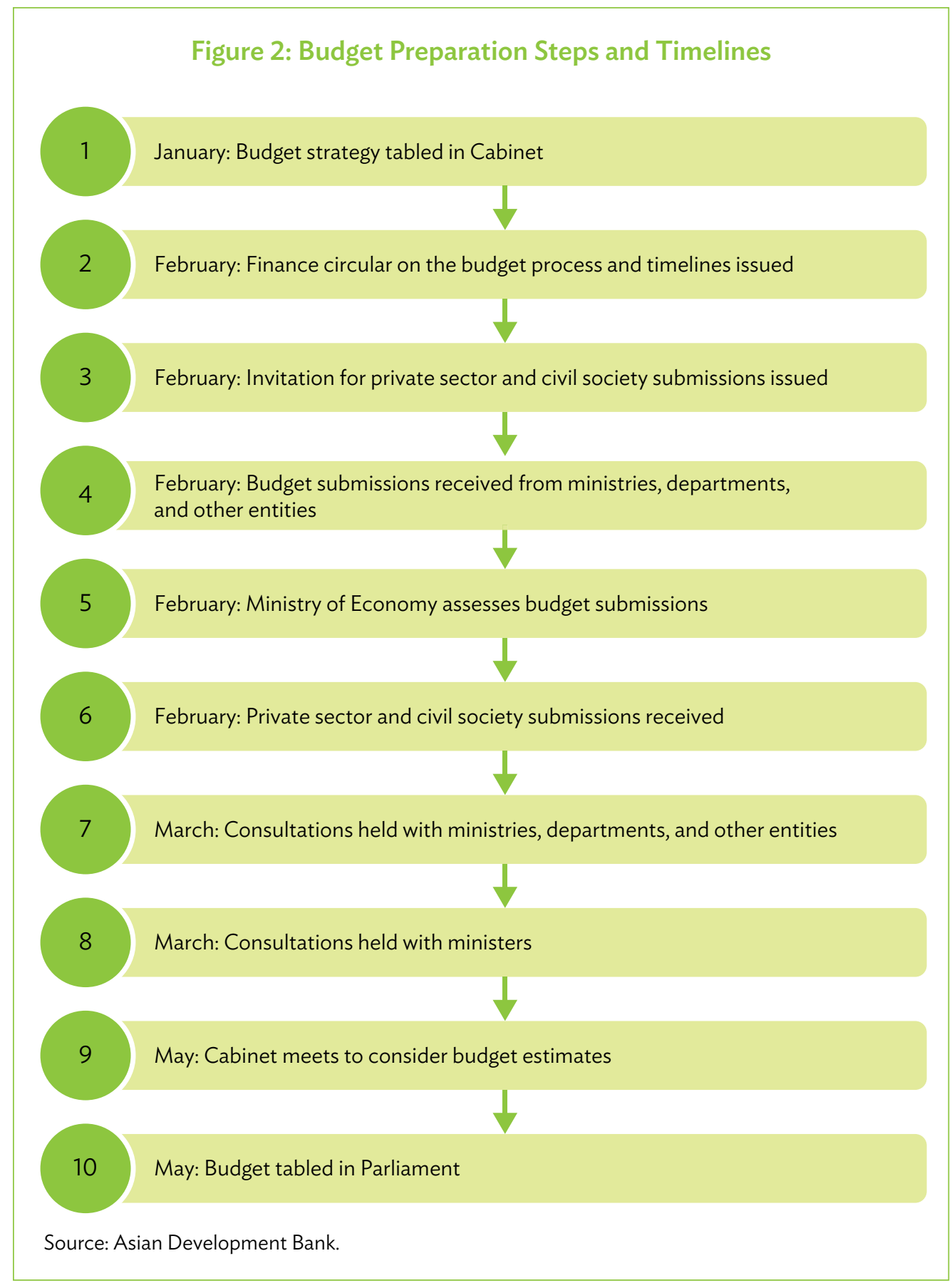

Further, the circular sets out operating expenditure measures, given the budget transfers; that agencies need to observe-commonly including cost-cutting measures, human resource policies, and effective use of operating grants.

The budget for capital expenditures comes from the Public Sector Investment Program (PSIP), which specifies the cost components of all capital programs. New projects are 
subject to proper feasibility assessment or cost-benefit analysis. Budget submissions must follow templates issued by the MOE, which requires ministries and departments to state the project summary, rationale, policy context, structure, costing, benefits, viability, proposals for implementation and management, and sustainability. The PSIP is integral to the formulation of the government's capital (including project) budgets. It consists of a 3-year pipeline of capital and project expenditure for funding by government and development partners. ${ }^{33}$ The phases of the PSIP are shown in Figure 3.

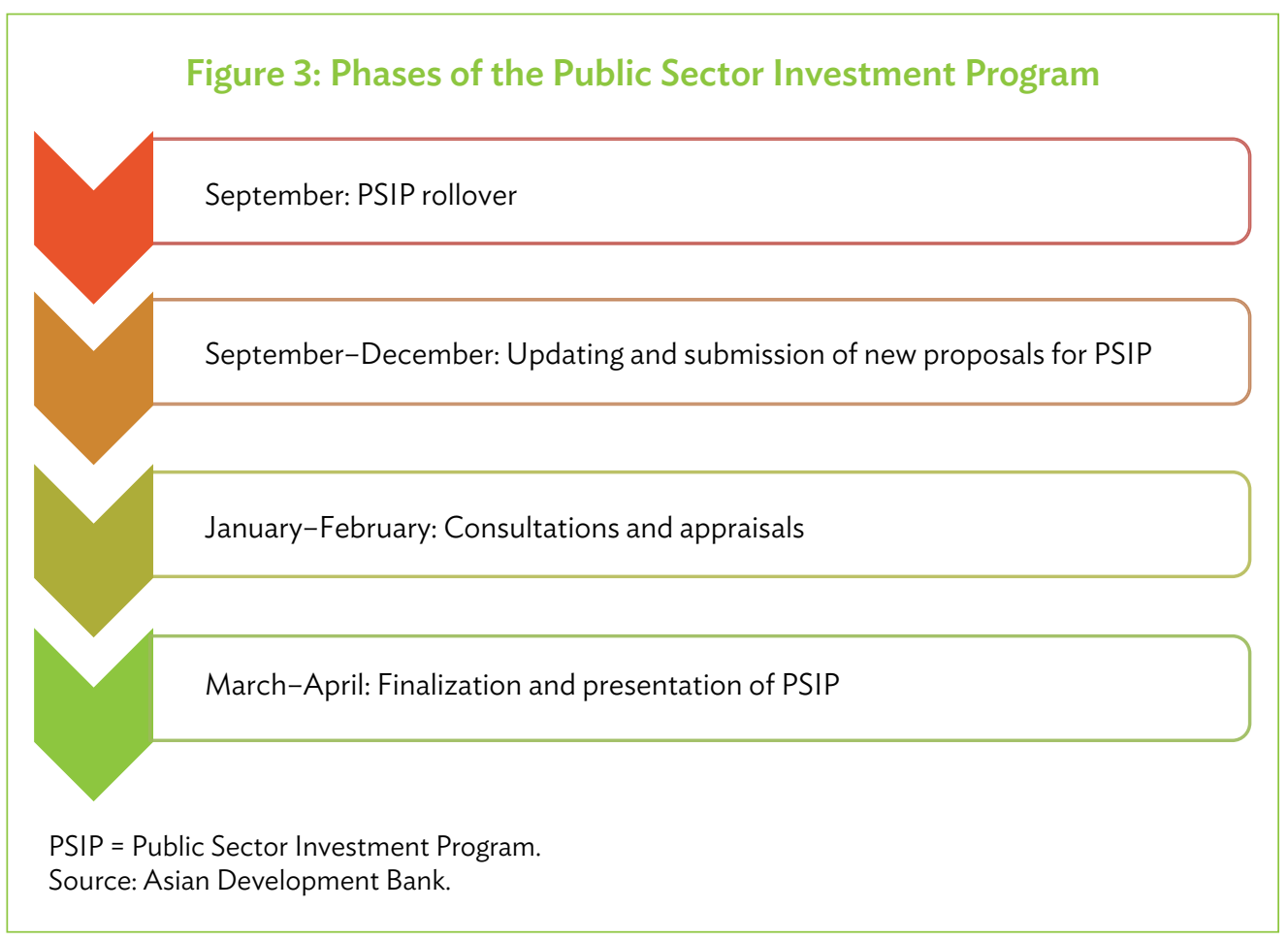

The capital and project budgets submitted are channeled through the PSIP process at the Strategic Planning Office of the MOE. ${ }^{34}$ This ministry formulates the PSIP programs and capital budget, and monitors the implementation of capital projects. This process is traced in Figure 4.

Following the receipt of the agencies' budget submissions and before the expenditure budget is finalized, the minister of economy holds a series of consultations with the line agencies. Consultations with the public through open forums, where individuals, civil society, nongovernment organizations, and the private sector are invited to contribute to the national budget have also been strongly encouraged lately. The public may likewise make written submissions to the MOE, which are compiled, assessed, and presented to the minister of economy. The budget is finalized and tabled in Parliament in June.

33 Ministry of Economy. 2010. Public Sector Investment Programme 2011-2013. MOE Circular Memorandum. 10 March. Suva.

34 Ministry of Economy. 2013. 2014 Budget Strategy and Baseline Budget. MOE Circular. No. 17/2013. 19 July. Suva. 


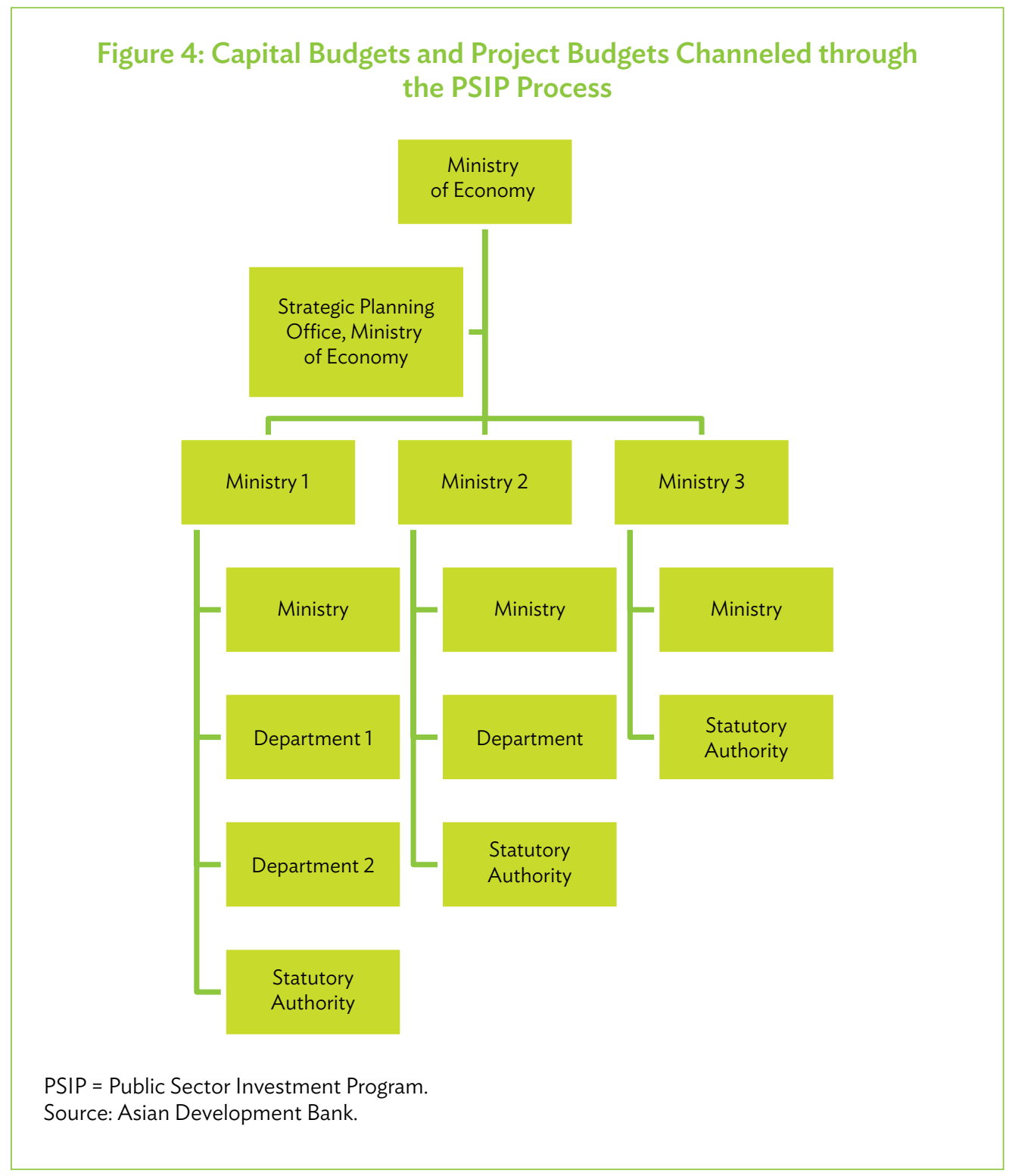

The MOE monitors the implementation of government agency budgets and prepares periodic budget implementation reports using the FMIS. Each report takes the form of a cash flow statement that conforms to the government finance statistics standards of the International Monetary Fund. The MOE effectively retains control over budget implementation by monitoring these reports. The cash flow statement (which breaks down cash flows between operating, investing, and financing activities) facilitates more relevant fiscal analysis as it reveals the type of operations from which money was received or on which it was spent. The MOE is responsible for budget recording and reporting is handled by the MOE; however, primary recording is managed by the ministries and the project executing agencies. The Strategic Planning Office, Ministry of Economy, also maintains reports on the capital projects. 


\section{B. Budget Recording and Reporting}

The FMA provides for the existence of the Consolidated Fund, where public monies are to be paid. ${ }^{35}$ The Consolidated Fund account is managed centrally by the MOE for efficient cash management. Withdrawals of public money can be made only with authorization from Parliament through an appropriation act. The FMA also provides for the creation of the Consolidated Trust Fund account, where monies other than public monies are to be paid. ${ }^{36}$ The monies are retained by the government and kept in a separate bank account pending their withdrawal for use or investment. For example, immigration bonds are monies held for foreigners who are employed under work visas. These bond monies are used to meet the cost of airfare in the event that the foreigners are deported for a breach in the terms of their employment.

The chief accountant of the MOE authorizes the opening of a new trust account, and records the receipt or payment of trust money in a separate cashbook or set of ledger accounts. The trust account is balanced and reconciled with the trust account each month. ${ }^{37}$

The Consolidated Fund account and the Consolidated Trust Fund account are shown in Figure 5. The Consolidated Fund contains monies that are

(i) used for the operations of the government;

(ii) borrowed by the minister of economy on behalf of the government to fund budget deficits, or to achieve purposes authorized under Parliament resolutions (e.g., additional appropriation required for rehabilitation work following a natural disaster), or to cover overdrafts or advances (e.g., when it is necessary for the bank accounts to be overdrawn) as also determined by Parliament; 38

(iii) lent by the MOE to those within or outside Fiji, ${ }^{39}$ through an appropriation by Parliament and evidenced by a loan instrument; and

(iv) invested by the MOE through fixed bank deposits, securities issued by a government agency, or advances or investments under the Trustee Act as resolved by Parliament. ${ }^{40}$

Government bonds are raised to cover budget deficits whereas treasury bills are floated to cover the short-term needs of the government. According to the audited WOG accounts as of 31 December 2013, government debt stood at $\mathrm{F} \$ 3.83$ billion ( $\$ 2.04$ million) August. ${ }^{41}$

The Government of Fiji lends to the Fijian Affairs Board, to individuals for tertiary education, and to government agencies such as the Copra Industry Stabilization Fund, Fiji Pine, Fiji Sugar Corporation, Viti Corporation, National Trading Corporation, and Rewa

\footnotetext{
Government of the Republic of Fiji. 2004. Financial Management Act. Section 9. Suva.

Government of the Republic of Fiji. 2004. Financial Management Act. Section 25. Suva.

Government of the Republic of Fiji. 2004. Financial Management Act. Section 58. Suva.

Government of the Republic of Fiji. 2004. Financial Management Act. Section 59. Suva.

Government of the Republic of Fiji. 2004. Financial Management Act. Section 61. Suva.

Government of the Republic of Fiji. 2004. Financial Management Act. Section 55. Suva.

$\$ 1=F \$ 1.8771$ as of 31 December 2013.
} 
Figure 5: Consolidated Fund Account and

Consolidated Trust Fund Account
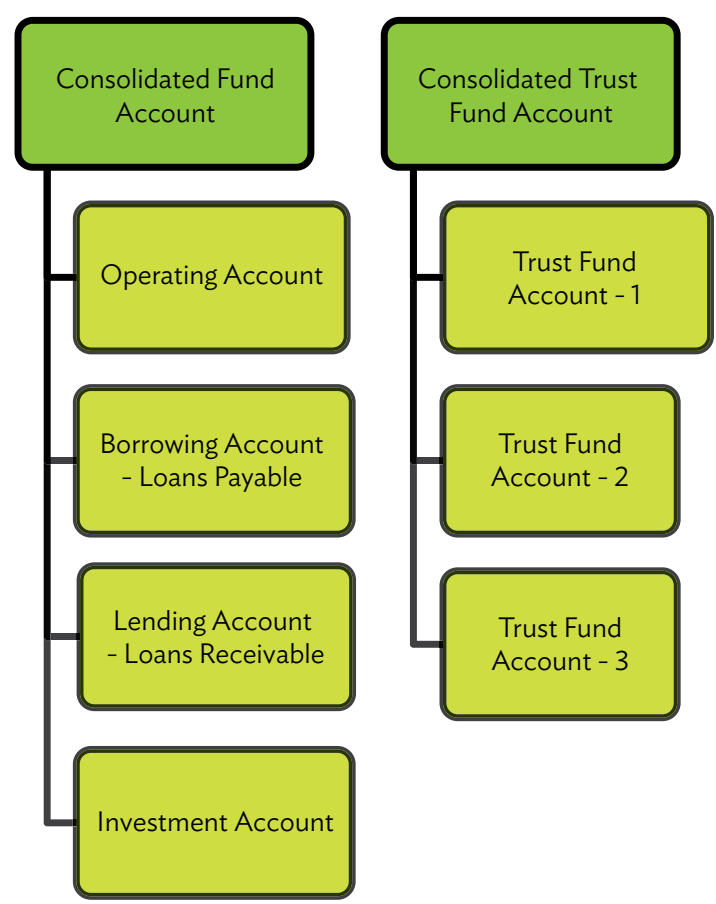

Source: Asian Development Bank.

Rice. The audited WOG accounts disclosed that the government lending account stood at F\$58.4 million ( $\$ 31.1$ million) as of 31 December 2013.

The Government of Fiji invests in equity in GCCs and CSAs, and the TMAs of ministries and departments. These totaled F\$496.2 million ( $\$ 264.3$ million) as of 31 December 2013.

Government of Fiji funds or counterpart funds for capital projects are sourced from Fiji Consolidated Fund accounts. The budget or proposed drawdown amount for the counterpart funds for the next financial year is agreed on and approved by both parties before it is entered into the budget documents. The loan is disclosed in the WOG financial statements.

Apart from the WOG financial statements reported by the various sectors (economic and infrastructure, financial services, social services, general administration), government entities, through their line minister, table individual reports in Parliament. The auditor general also submits separate reports for GCCs, CSAs, municipal councils, and provincial councils each year. 


\section{State Entities}

The Government of Fiji has $11 \mathrm{GCCs}^{42}$ and six CSAs where it has a 100\% shareholding. It also has six majority-owned companies MOCs and a minority shareholding (MIC) in one company (see Appendix 1). The returns on investments from these state entities in 2013 (measured in terms of return on assets) were GCC: $4.9 \%$, CSA: $2.9 \%$, MOC: $5.2 \%$, and MIC: $5.8 \%$. The returns on equity were GCC, $5 \%$; CSA, $5.9 \%$; MOC, $8.1 \%$; and MIC, $11.5 \%{ }^{43}$

Each of these entities operates independently under a board of directors appointed by the minister of public enterprises in accordance with section 56 of the PEA 1996. For GCCs, the board is responsible for the following:

(i) setting each GCC's commercial direction and policy;

(ii) appointing the chief executive officer;

(iii) ensuring that the GCC achieves its principal objective, which is to run a successful business and to be as profitable and efficient as a comparable entity not owned by the state; ${ }^{44}$

(iv) ensuring that the GCC operates in accordance with its corporate plan and carries out its objective under its statement of corporate intent;

(v) being accountable to the minister of public enterprises for its performance as required under the PEA and any other acts that apply to the GCCs; and

(vi) ensuring that the GCC performs its functions properly, effectively, and efficiently. ${ }^{45}$

As companies governed by the Companies Act, the GCCs, the MOCs, and the MIC have their own budgets and generate revenues from the goods and services they produce and sell. Their budgets are therefore not rolled up into the central government budget. ${ }^{46}$

The CSAs are not subject to direction by the government or any authority, in accordance with section 83 of the PEA. Like a GCC board, a CSA board will ensure that the entity operates independently in accordance with its corporate plan. CSA budgets are also not part of the central government budget. ${ }^{47}$

The budgets of statutory authorities are included in the budgets of their line ministries or the ministries to which they are responsible in their operations and performance. For example, the budget of the Land Transport Authority is provided as an operating grant under the Ministry of Infrastructure and Transport; that of the National Fire Authority, under the Ministry of Local Government, Housing and Environment; and that of Tourism Fiji, under the Ministry of Industry, Trade and Tourism.

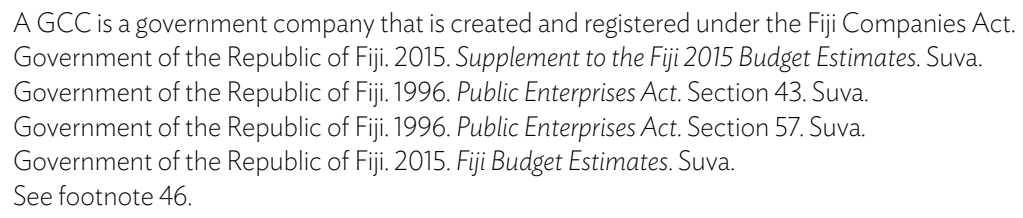


Only two statutory authorities - the Water Authority of Fiji and the Fiji Roads Authorityare provided their own budgets in the 2015 budget estimates, separate from the budgets of their line ministries. The budget process for the two entities is therefore similar to that for the ministries and departments. 


\section{Onlending Arrangements}

The World Bank, in its Debt Management Performance Assessment (DeMPA) report of January 2014, states that Fiji has no documented policies or procedures for onlending. The current practice involves consultations on onlending transactions, contract conditions, and potential beneficiary agencies or SOEs. These consultations are held in parallel with external loan negotiations. The MOE and the beneficiary agency discuss and come to an agreement on the terms of the onlending arrangement, which will be finalized by $M O E$ under section 61 of the FMA. ${ }^{48}$

The World Bank report adds that two current active onlending agreements (two loans from the Export-Import Bank of China) are to be monitored by the MOE. These two loans relate to the implementation of a social project and the construction of low-cost housing facilities. In the World Bank's view therefore the situation requires the development of a comprehensive analytical framework for analyzing the financial viability of beneficiaries of such funds.

There are currently no onlending arrangements for ADB-financed projects in Fiji.

48 DeMPA is a methodology for assessing public debt management performance through a comprehensive set of indicators spanning the full range of government debt management functions. It is based on the Public Expenditure and Financial Accountability framework, the internationally recognized standard for diagnostic assessments of public financial management. The DeMPA tool presents the 15 debt performance indicators along with a scoring methodology. A complementary guide provides additional information for the use of the indicators. 


\section{Foreign Exchange and Interest Rate Risks}

$T^{\text {hen }}$ he Reserve Bank of Fiji (RBF) regulates the issue of currency and the supply, availability, and international exchange of money. It also promotes sound financial structure and monetary stability, among other responsibilities. Part II, section 4, of the Reserve Bank Act states the main objectives of the bank, which are as follows:

(i) to regulate the issue of currency, and the supply, availability, and international exchange of money;

(ii) to promote monetary stability;

(iii) to promote a sound financial structure;

(iv) to foster credit and exchange conditions conducive to the orderly and balanced economic development of the country;

(v) to regulate the insurance industry; and

(vi) to regulate the capital markets and securities industry.

The RBF ensures monetary stability through the supply of money, and through the targeting of an inflation rate or interest rate that will result in price stability and increased confidence in the Fiji dollar. The monetary policy will also help stabilize the economy, reduce unemployment, and maintain the forecast foreign exchange rates. In managing domestic monetary conditions, the RBF monitors those conditions, provides advice, and plays a leading role in managing the government's cash flow. As fiscal agent for the government, the RBF issues government bonds and floats Treasury bills to meet the government's budget deficits in the short and the long term. It also manages and regulates payment systems, and administers the interbank money market.

Foreign exchange risks and interest rate risks are managed effectively by the government through the monetary policies of the RBF. As provided in the government's 2015 Budget Supplement, the monetary policy has retained its focus on its twin objectives of low inflation and a comfortable level of foreign reserves, and will continue to closely monitor international and domestic developments, and to align policies accordingly, to secure those twin objectives. As the government does not onlend to project management units, the foreign exchange risks do not pass to the projects but are managed by the government through the RBF. 


\section{Funds Flow Arrangements}

The funds flow arrangements define the flow of funds, the approval process, transfers

between entities, the related banking procedures, and the recording of disbursement.

The four modes of loan disbursements are reimbursement, imprest fund, direct payment, and commitment procedures. ${ }^{49}$

\section{A. Reimbursement Procedure}

Under the reimbursement procedure, ADB pays from the loan account to the borrower's account for eligible expenditures. The reimbursement procedure starts when a signed withdrawal application with a summary sheet is submitted to ADB. After ADB approves the application, it remits funds to the nominated bank account. Given the large volume of documents required, ADB will accept simplified documentation using two procedures: the statement-of-expenditure procedure; and the force-account-work procedure, under which two certificates are issued instead of the usual supporting documents. Figure 6 summarizes the reimbursement process of loan disbursement.

\section{Figure 6: Funds Flow Arrangements for ADB Projects Using Reimbursement Procedure}

Signed withdrawal application submitted to ADB with summary sheet

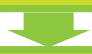

ADB registers its satisfaction with the application and supporting documents by approving the application

$A D B$ remits money to the nominated bank account

$\mathrm{ADB}=$ Asian Development Bank.

Source: ADB. 2015. Loan Disbursement Handbook. Appendixes 7a and 7b. Manila.

49 In case of conflict between ADB's procedures described in this report and the procedures in ADB's guidelines (Loan Disbursement Handbook 2015, or as amended from time to time), the procedures described in ADB's guidelines will prevail. 


\section{B. Imprest Fund Procedure}

Under the imprest fund procedure, ADB assesses the usefulness of an imprest account during project preparation. If the need for such an account is established, the borrower opens a bank account to receive advances for the exclusive use of the project, and submits to ADB a signed withdrawal application together with supporting documents. ADB, after approving the application, makes an advance disbursement from the loan account for deposit to the imprest account. The imprest fund process of loan disbursement is illustrated in Figure 7.

Figure 7: Funds Flow Arrangements for ADB Projects Using Imprest Fund Procedure

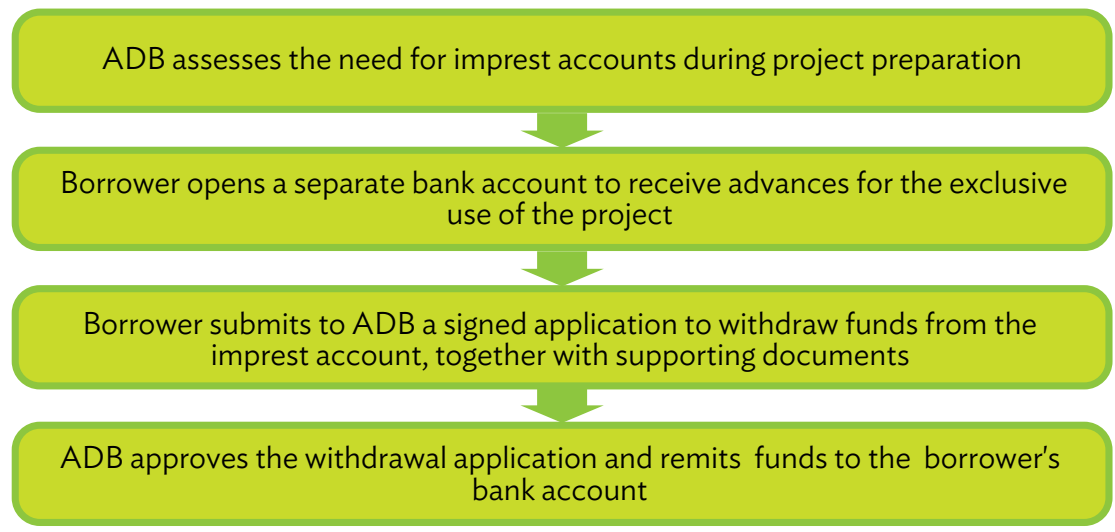

ADB = Asian Development Bank

Source: ADB. 2015. Loan Disbursement Handbook. Appendix 10a. Manila.

\section{Direct Payment Procedure}

The direct payment procedure is a disbursement procedure where ADB pays the designated beneficiary (e.g., supplier, contractor) at the borrower's request. The procedure starts when the contractor submits to the ministry overseeing the project a signed withdrawal application with the required supporting documents. The technical or professional staff at the ministry certifies the claim and forwards it to the executing agency. At the executing agency, the technical or professional staff verifies the claim and sends a copy to its finance department for payment of the government's share, and the original claim to MOE for payment of ADB's share. The executing agency's finance department processes the payment of the government's share and records the ADB portion in its ledgers. The MOE certifies the (approved) original claim and sends it to ADB for the processing of ADB's share of the claim. ADB remits its share of the payment to the contractor's bank account. The direct payment procedure is shown in Figure 8. 


\section{Figure 8: Funds Flow Arrangements for ADB Projects Using Direct Payment Procedure}

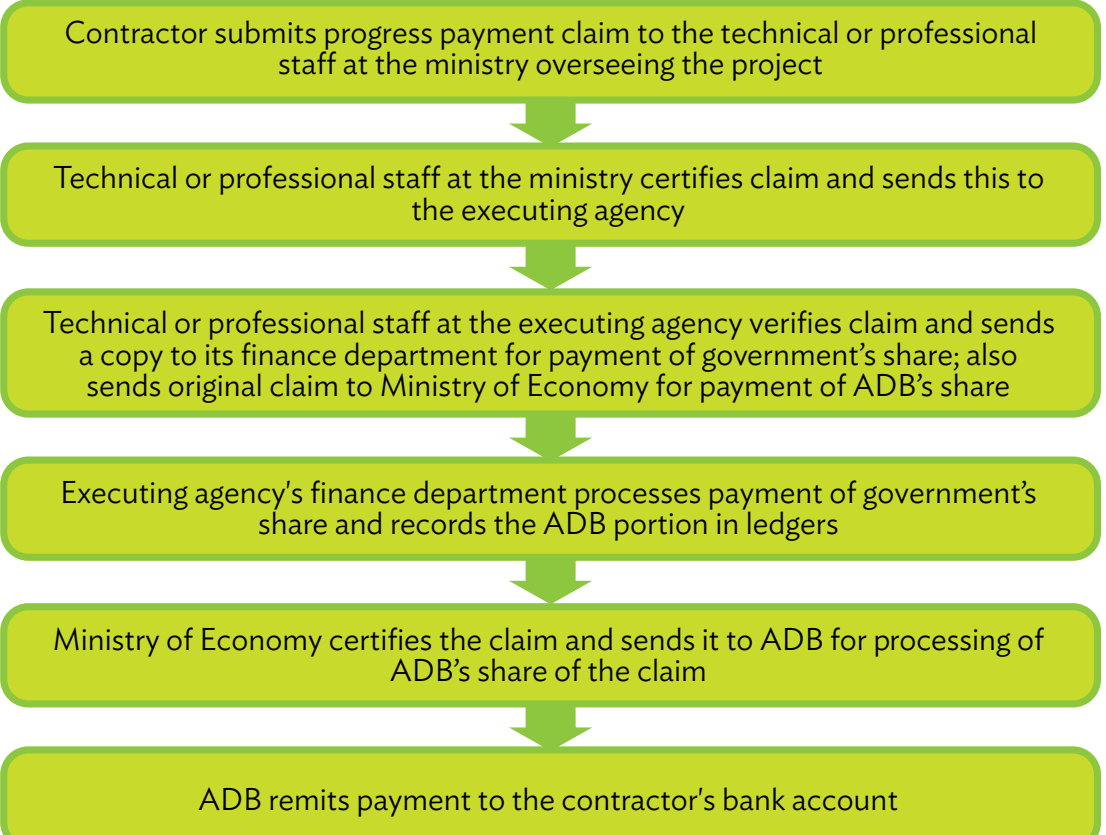

$\mathrm{ADB}=$ Asian Development Bank.

Source: ADB. 2015. Loan Disbursement Handbook. Appendixes 7a and 7b. Manila.

\section{Commitment Procedure}

Under the commitment procedure, $\mathrm{ADB}$ agrees to reimburse a commercial bank for payments made against a letter of credit, at the borrower's request. The reimbursement is limited to the amount in the loan account. The letter of credit issued by the borrower's bank takes effect when ADB issues its commitment letter to the negotiating bank. The funds flow arrangements under the commitment procedure start when the borrower submits an application to ADB. When the application is approved, ADB issues a commitment letter. The acceptance of the commitment letter is made when the nominated commercial bank requests payment. ADB will process the request and remit payment to the nominated commercial bank. The commitment procedure is summarized in Figure 9. 


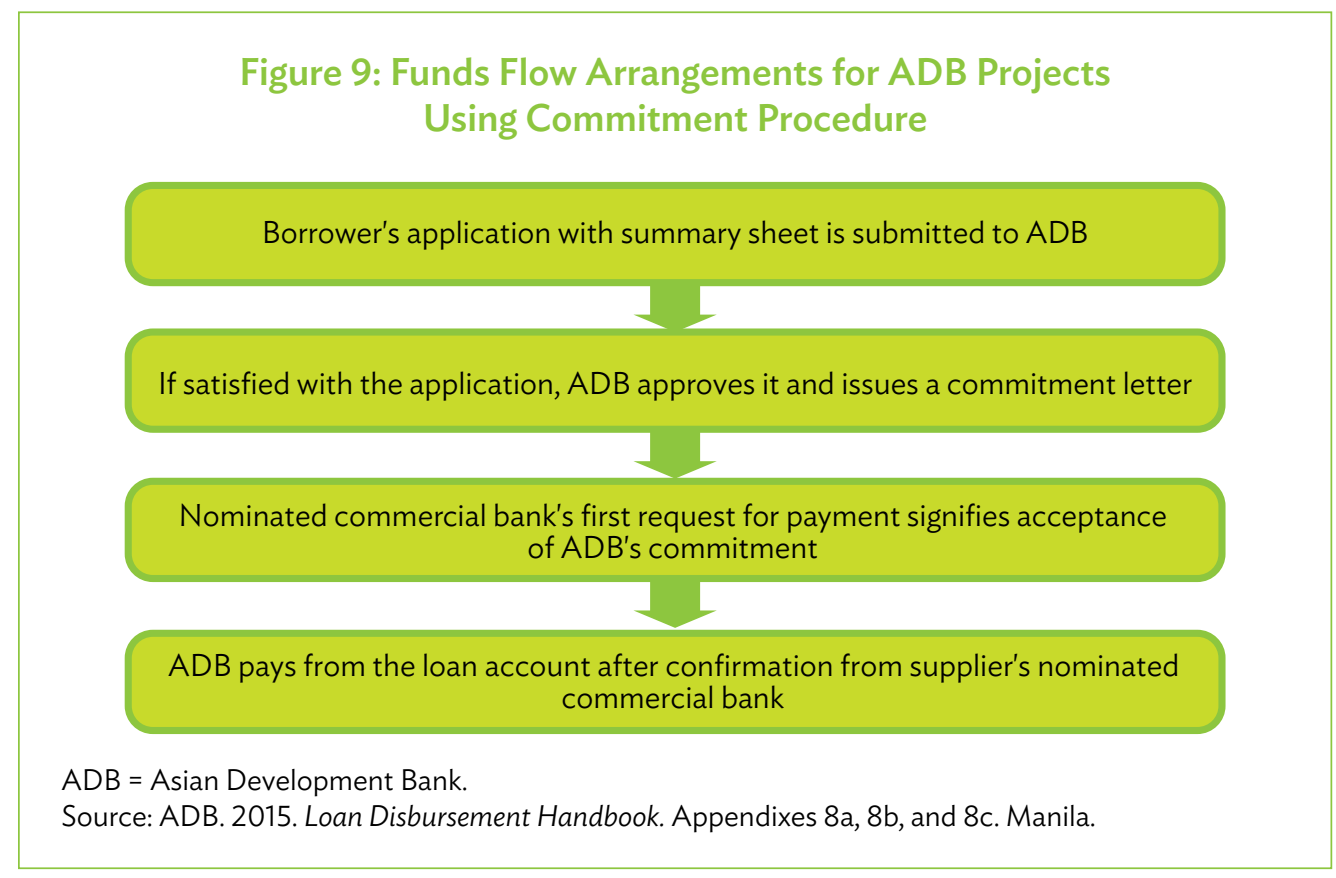




\section{Accounting and Reporting}

\section{A. Accounting Standards}

The WOG financial statements are prepared in accordance with section 46 of the

FMA 2004. Given the government's quasi-cash environment, the modified accrual basis of accounting is used in the preparation. ${ }^{50}$

As specified by the Fiji Institute of Accountants, the GCCs and the CSAs adopt the full International Financial Reporting Standards (IFRS) or the IFRS for small and medium enterprises, depending on the size of the entities. ${ }^{51}$

According to the Fiji Institute of Accountants By-Laws, the full IFRS is applicable to all undertakings that fall within any of the following categories:

(i) public companies, as defined in the Companies Act;

(ii) government MOCs;

(iii) banking and financial institutions;

(iv) superannuation, insurance, and insurance broking entities;

(v) government entities established under their own statute with annual turnover of at least $\mathrm{F} \$ 5$ million;

(vi) entities that consistently over a period of 2 years comply with at least two of these three criteria:

(a) have recorded consolidated revenue of more than $\mathrm{F} \$ 20$ million for each of the financial years,

(b) have recorded total assets exceeding $\mathrm{F} \$ 20$ million at the end of each of the financial years, and

(c) have more than 50 employees at the parent and controlled entities at the end of each financial year;

(vii) publicly accountable entities with annual turnover of at least $\mathrm{F} \$ 5$ million, which have debt or equity instruments on public issue or have coercive power to tax, rate, or levy to obtain public funds; and

(viii) undertakings where any of the entities listed above have significant influence (through more than $20 \%$ ownership), provided that the turnover of such entities exceeds $\mathrm{F} \$ 5$ million, as equity accounting would be applicable to the parent company reporting (see Appendix 2).

Office of the Auditor General. 2013. Fiji Whole of Government Audited Accounts. Note 1(a). Suva.

Fiji Institute of Accountants. 1986. By-Laws. Suva. 
The standards used for projects are the standards of the executing agency. For example, ADB's Third Fiji Road Upgrading Project (FRUP3) ${ }^{52}$ used the IFRS, which the Fiji Roads Authority follows. ${ }^{53}$

\section{B. Cash Basis International Public Sector Accounting Standards}

The WOG financial statements comprise the consolidated accounts of the central government and its ministries and departments. Fiji moved from the modified accrual basis of accounting to the Cash Basis International Public Sector Accounting Standards (IPSAS) in fiscal year 2016.54 This change was one of the many reforms recommended by the Pacific Financial Technical Assistance Centre (PFTAC) Mission in March $2015^{55}$ to improve public financial management in the country. The adoption of the Cash Basis IPSAS framework is a stepping-stone toward the adoption of Accrual Basis IPSAS. This change entailed a review of the FMA, which was completed in February 2017. Another initiative, which is part of the first phase of transitional issues approved by the minister of economy, involves strengthening the analysis of reconciliations submitted by ministries and departments to ensure that errors and unsubstantiated figures in the general ledger are identified and properly corrected. The aim is to address the lack of reconciliation that has featured prominently in reports of the auditor general.

The accounting standards adopted by government entities are IFRS for small and medium enterprises, and Cash Basis IPSAS for all other entities. These standards are guided by the Fiji Institute of Accountants By-Laws (Appendix 2). Project financial statements for projects funded by development partners use the reporting framework adopted by the executing agencies.

\section{Accounting Systems}

\section{Chart of Accounts}

The chart of accounts of the Government of Fiji is based on the format of the Consolidated Fund account and the Consolidated Trust Fund account. It provides various subsidiary accounts that facilitate the preparation of the WOG accounts. All government ministries' and departments' accounts are processed through the FMIS at the MOE, but entries into the system and reports can be accessed by the entities at their localities. The ministries and departments also manage reconciliations, although the 2013 audited accounts revealed some discrepancies in the reconciliations. Entities that use the IFRS will have charts of accounts that are not consistent with government accounts.

\footnotetext{
ADB. 2015. Completion Report: Third Road Upgrading (Sector) Project in the Republic of Fiji. Manila.

Government of the Republic of Fiji. 2014. Fiji Roads Authority: 2013 Annual Report. Suva.

Interview with Chief Accountant Necani Lagicere of the Ministry of Economy, 28 July 2015.

Pacific Financial Technical Assistance Centre (PFTAC). 2015. Fiji: Progress Review of Accounting Reform. Suva.
} 


\section{Internal Control}

The IAGG division of the MOE conducts the following according to the Finance Instructions 2010:56

(i) It determines if the operations or activities of budget sector agencies are being performed effectively, economically, and efficiently, and are in compliance with all relevant laws.

(ii) It evaluates the financial affairs of budget sector agencies for compliance with all relevant written laws, with due regard to the principles of responsible financial management.

The IAGG is currently performing a mixture of compliance and performance audits and is slowly moving toward modern evaluation. Its staff has been trained in TeamMate audit software and are looking forward to using it in 2016.

Furthermore, the permanent secretary for finance may authorize the IAGG to conduct the following:

(i) a special investigation into the financial management of any budget sector agency;

(ii) a special investigation into the financial management of any state entity under the authority of the line minister; and

(iii) an audit of the accounts of any recipient of government grants to the extent necessary to ensure that any conditions of any grant made to it by the state have been complied with.

However, there is no specific requirement for the IAGG to evaluate the adequacy of internal controls in the ministries and departments. The IAGG's work is focused on carrying out special investigations. The ministries of health, infrastructure and transport, agriculture and education have their own internal audit teams, which report to the permanent secretary for finance through the IAGG director. Government entities may commission accounting firms to conduct an internal audit of systems and controls.

Follow-up work is done by the IAGG as part of the internal audit process. A form is completed periodically by the team to track the various actions taken by the audited entity regarding the internal audit findings and recommendations.

\section{Accounting System}

The Government of Fiji uses FMIS Masterpiece, a computer-integrated system software that facilitates and administers the accounting system of the government. The software was introduced to improve the financial management practices of the government, mainly through fund controls to avoid overspending by ministries. ${ }^{57}$

Ministry of Economy. 2010. Finance Instructions 2010. Section 72. Suva.

Ministry of Economy. www.economy.gov.fj 
The FMIS currently uses five modules: fund accounting, purchasing, accounts payable, accounts receivable, and general ledger. Other modules, such as bank link, fixed assets, and job costing, are available but are yet to be used or have not been used fully.

(i) Fund accounting. Following the budget announcement, ministries, departments, and other entities submit their monthly cash flows, which are entered into the FMIS by the MOE. This information is accessed by the entities when checking the availability of funds before using their budget.

(ii) Purchasing. The purchasing process begins with a request for purchase by the division of a ministry, which is sent with three quotations to the head of the ministry or a delegate for approval. Once the request is approved, information such as vendor, item names and descriptions, item numbers, unit costs, and delivery schedules will be entered into the FMIS by the buyer. Following the receipt of items purchased, the invoice is sent to the accounts payment section for processing of payments.

(iii) Accounts payable. The accounts payable module has an important role in the financial cycle of an organization. Once the vouchers are prepared, vendor accounts are updated or new ones are created. Payment is made by check or through electronic funds transfer (EFT).

(iv) Accounts receivable. Accounts receivable are considered only for agencies that meet the following criteria:

(a) They sell or provide goods and services that can be paid for a later date; or

(b) For one of their core functions, they levy an annual fee, which must be paid in the previous year.

(c) The accounts receivable module handles billing, tracks credit limits to reduce the risk of overextended accounts and bad debts, calculates finance charges, and produces invoices and statements. It tracks sales and taxes for multiple ship-to locations.

(v) General ledger. This module is where all financial transactions and related amounts are recorded after they have been processed in the various other modules. The chart of accounts and the account processing tables are also maintained within this module. The general ledger module is the core module in any financial system and records financial transactions at a summary level. It is from this module that all financial reporting is done.

\section{Financial Management System}

The financial management system is the process of managing financial resources, and covers accounting and financial reporting, budgeting, collection of accounts receivable, and risk management. The accounting and financial reporting function is facilitated by the financial management information system unit.

\section{Financial Management Information System Unit}

The FMIS unit of the MOE facilitates and administers the accounting system and processes of the central government and its ministries and departments. The core responsibilities of the unit are as follows: 
(i) support in budget preparation and execution;

(ii) collection, analysis, and reporting of financial information in financial statements, for effective monitoring and decision making; and

(iii) facilitation of annual financial statement preparation and reporting.

The WOG financial statements are generally submitted on time to the auditor general. Prior to the general elections in 2014, the audited accounts were submitted on time to the Cabinet, and to the Speaker (in 2015).

The FMIS adopts the fund accounting approach. Fund accounting allows the government to track expenditures against the approved budget and ensures that ministries and departments spend within their approved budget. The approach makes it easier to identify which monies are available for specific purposes. The fund accounting process is shown in the flowchart in Figure 10. Since the passage of an appropriation act, the ministries and departments must submit their monthly cash flows for the budget year to the MOE. The FMIS unit enters the cash flow into the FMIS, which the ministries or departments can access when using their budget allocations.

\section{Figure 10: Fund Accounting Flowchart}

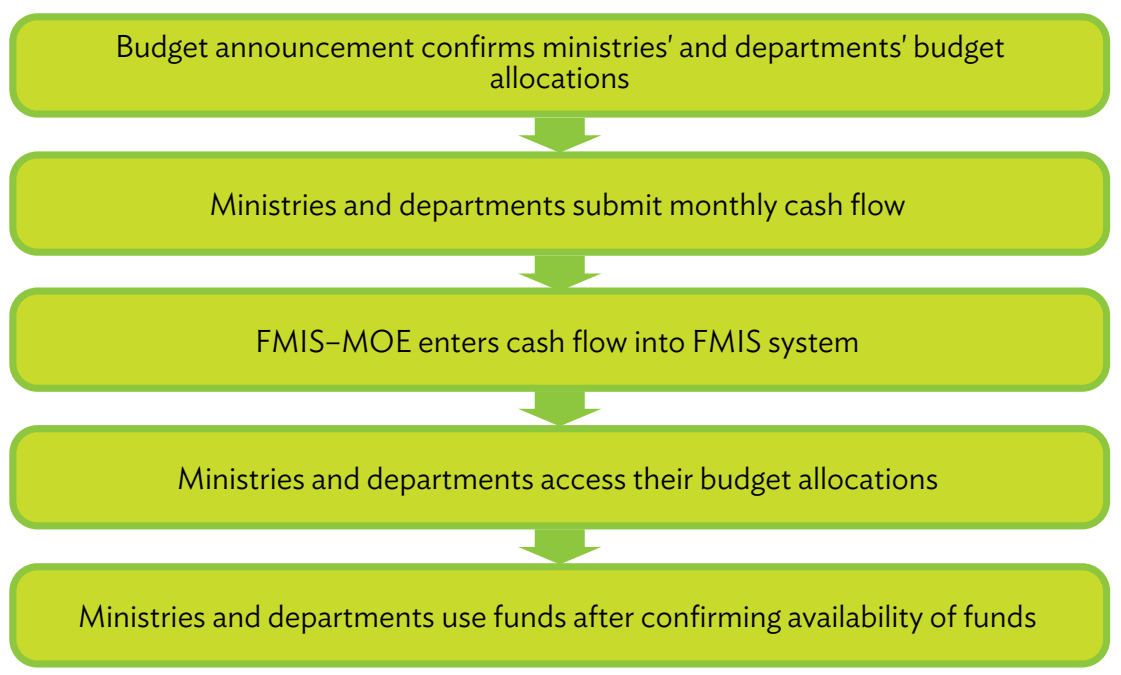

FMIS = Financial Management Information System, MOE = Ministry of Economy .

Source: Based on information obtained from the financial management information system unit, Ministry of Economy.

\section{Responsible Units}

The responsible units for $\mathrm{ADB}$ projects are as follows:

(i) the contractor, which actually does the work;

(ii) the relevant ministry, which oversees the project; 
(iii) the executing agency, which manages the project and processes the government's share of the claims;

(iv) the MOE, which certifies the contractors' claims for processing; and

(v) ADB, which processes the bank's share of the claim.

\section{E. Fiscal Year}

The fiscal year for ADB projects is usually the same as the fiscal year of the executing agency.

\section{F. Project Financial Statement Preparation}

ADB project financial statements have always been prepared on time for the auditor general to audit and, over the years, the audited statements have been sent back to ADB on time. For example, the latest audited financial statements for 31 December 2013 of the ADB FRUP 3 Supplementary Loan project were completed and signed on 23 April 2014. ${ }^{58}$

The transition of the executing entity from ministry status to SOE will strengthen the preparation of project financial statements. The ministry's financial information system now contains only cash data and restricts the use of accrual accounting and financial reporting for projects. As the financial statements are produced under the FMIS at the MOE, the accounting information could have the same shortcomings described above. Also, the tabling of financial data 9 months after the end of the financial year results in delays in the submission of reports.

ADB. 2009. Audited Financial Statements: Third Road Upgrading (Sector) Project in the Republic of Fiji. Manila. 


\section{Auditing Arrangements}

\section{A. Auditing Requirements}

ection 152 of the Constitution of the Republic of Fiji empowers the auditor general to audit and report on the public accounts of the state, the control of public moneys or public property of the state, and all transactions with or concerning the public moneys or public property of the state. The Audit (Amendment) Act 2006 further authorizes the auditor general to audit

(i) the accounts of the Consolidated Fund;

(ii) the WOG financial statements and the annual appropriation statement that must be included in the WOG annual report for each financial year under the FMA;

(iii) the accounts of state entities, except those of the OAG and off-budget state entities;

(iv) the financial statements that must be included in a state entity's annual report;

(v) the accounts of any entity whose borrowings have, in whole or in part, been guaranteed by the government, but only if and to the extent that the minister has authorized or required the audit;

(vi) the accounts of any externally aided projects;

(vii) the financial management of any state entity; and

(viii) the accounts of any entity, to the extent necessary, to ensure compliance with any conditions of the grant set by the state.

The auditor general is also empowered by the Audit (Amendment) Act 2006 to conduct performance audits to determine whether an entity is achieving its objectives effectively and doing so economically and efficiently, and whether the operations or activities of state entities are being performed effectively, economically, and efficiently. ${ }^{59}$

The OAG follows the International Standards on Auditing (ISA) as required for professional accountants and auditors who are members of the Fiji Institute of Accountants. The ISA covers specific aspects of auditing such as understanding the audited entity; determining the audit objectives, scope, and assertions; assessing risks and determining materiality; determining the audit approach and audit program; assessing control procedures; conducting an analytical review; determining the sampling approach; performing substantive procedures; gathering audit evidence and documentation; performing audit evaluation; and writing the management letter and the audit report. 
A complete set of 37 standards and auditing guidance statements was brought into force for the audit of financial statements covering periods beginning on or after 1 January 2002. These standards were predominantly based on the ISA issued by the International Federation of Accountants (IFAC) at that time. They have since been replaced by the current set of audit-related standards issued by IFAC effective 1 July $2008 .{ }^{60}$

The OAG has yet to adopt the International Standards of Supreme Audit Institutions, the auditing standards for public sector audit institutions adapted from the ISA. These standards consist of the founding principles, prerequisites for the functioning of supreme audit institutions (or government audit institutions), fundamental auditing principles, auditing guidelines, and guidance for good governance from the International Organisation of Supreme Audit Institutions. ${ }^{61}$ The OAG staff members are accounting graduates and qualified professionals. In cases where there is a limited number of qualified staff, or where there are competing priorities and strict audit completion dates (especially for SOEs), the audits are contracted out to the private sector. In such a situation, the auditor general is still required to sign the audit plan, review the audit files, conduct the exit meetings, and sign the audit report.

Prior to the audit of the WOG accounts, a government entity, or an ADB-financed project, an audit plan is produced and discussed with the audited entity in an entry interview meeting. After the audit, an internal control memorandum covering the weaknesses or deficiencies of internal control systems or any related matters that need to be brought to the attention of the audited entity is produced. The internal control memorandum also contains the auditor general's recommendations and the entity's response.

In addition, the auditors produce an audit highlights memorandum, which brings out significant audit findings and is the basis for the preparation of the audit management letter. The purpose of the audit highlights memorandum is to summarize all significant matters relating to the entity's statement of accounts and the conduct of the audit. All major points of exception and significance relating to the adequacy of audit procedures and the fair presentation of financial statements are briefly documented.

The audit management letter is issued together with the audit opinion at the end of the audit. The management letter focuses mainly on reporting weaknesses that exist in the system of financial or accounting controls and the audited entity's internal controls. The letter will also report on significant irregularities that actually occurred or instances where regulations and set procedures were not applied consistently.

The internal control memorandum, the audit highlights memorandum, and the audit management letter are used in the discussion of the audit observations with the audited entity at the exit interview meeting. The audit opinion, which is in draft form at that stage, is usually agreed on during this meeting. The auditor general then finalizes and signs the audit opinion or report.

Fiji Institute of Accountants. 1986. By-Laws. Suva.

INTOSAI is the umbrella organization for the external government audit community. 
The auditor general is required to report the audit findings to Parliament through the speaker of the House of Representatives within 9 months after the year to which the audit relates, ${ }^{62}$ and to submit a copy of the report to the minister of economy. ${ }^{63}$ Reports on special investigations and performance audits must be submitted to the speaker of the House of Representatives within 6 months after the completion of the special investigations ${ }^{64}$ or performance audits. ${ }^{65}$ Once tabled by the minister of economy, ${ }^{66}$ the report is made public. The Public Accounts Committee is then required to deliberate on the report and submit its findings to Parliament. Audit reports must be submitted to Parliament on time.

\section{B. International Standards on Auditing}

The International Standards on Auditing are used by the OAG in its audits of government entities and projects, as specified in the 2013 audited accounts of government. The Audit (Amendment) Act 2006 states that the auditor general may conduct audits and special investigations in such manner as that official may deem appropriate, but must ensure that they are conducted competently and consider the auditor general's assessment of the effectiveness of internal control systems, relevant provisions of the Fiji Standards on Auditing issued by the Fiji Institute of Accountants, and any other relevant standards. The Fiji Standards on Auditing were adopted from the ISA. There are currently 36 ISA and one International Standard on Quality Control (ISQC) 1.67

\section{Shortcomings Identified through External Audits}

The audit of the 2013 WOG accounts revealed three major shortcomings, which have been addressed by the government. First, there were inadequate systems of internal control for "cash at bank" totaling F $\$ 25.5$ million. These inadequacies consisted of

(i) the absence of bank reconciliations and evidence of cash held for various overseas and domestic bank accounts;

(ii) unrecorded and overdrawn cash balances relating to domestic bank accounts; and

(iii) unexplained variances between the drawings account, the general ledger, and the respective Board of Survey reports.

\footnotetext{
Office of the Auditor General. 2006. Audit (Amendment) Act 2006. Section 12(1). Suva.

Government of the Republic of Fiji. 2013. Constitution of the Republic of Fiji. Section 152(13). Suva.

Government of the Republic of Fiji. 2006. Audit (Amendment) Act 2006. Section 12(2). Suva.

Government of the Republic of Fiji. 2006. Audit (Amendment) Act 2006. Section 12(3). Suva.

Government of the Republic of Fiji. 2013. Constitution of the Republic of Fiji. Section 152(14). Suva.

International Auditing and Assurance Standards Board. The Clarified Standards.
} 
Second, the accounts receivable balance totaling F $\$ 18.7$ million was not supported with reconciliations. Third, there was an absence of records for $F \$ 2.4$ million in advances to the Department of Agriculture. ${ }^{68}$

The WOG, ministries and departments, and project audits (except Fiji Roads Authority) were up to date with the completion of the 2014 accounts. However, the tabling of the reports by the minister of economy in Parliament, as required under the Fiji Constitution, was delayed. The 2015 accounts of the WOG, ministries, and projects were tabled by the minister of economy in Parliament in March 2017. However, there have been delays in the audits of some GCCs and CSAs, and municipal and provincial councils, which were due to delays in the preparation and submission of the accounts to the OAG. 


\section{Reporting and Monitoring}

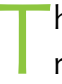
he reporting and monitoring of projects, including $\mathrm{ADB}$ projects, follow the same requirements as those imposed on the executing agencies. Where the executing agency is an SOE, the executing agency is governed by the requirements of the PEA 1996; if it is a statutory authority, it is governed by the respective legislation for that authority. The agency has a board that makes strategic decisions on the agency's budget, functions, and responsibilities, and monitors and reports on performance. The board also has the responsibility to report to Parliament through its line minister, and this responsibility is detailed in the agency legislation or the PEA for state-owned enterprises.

For example, the Fiji Roads Authority, which is responsible for the ADB FRUP3 project, ${ }^{69}$ was established as a corporate entity by Fiji Roads Authority Decree on 5 January 2012. Its objective is to provide effective management and administration of the country roads (which were previously managed by several different bodies) based on an outsourcing model with only a small number of core management and administration staff. The authority is governed by a five-person board of directors, who report to the line minister.

The annual budget is presented each year to the FRA board, which approves it and presents it to the MOE. Since the Fiji Roads Authority's inception, all budget submissions have been approved by the FRA board and the MOE.

The agency legislation or the PEA specifies the reporting requirements, including the frequency of monthly, quarterly, semiannual, and annual reports, and these have both financial and physical performance updates, which are discussed by the agency board in its meetings.

Some useful references and suggested readings are listed in Appendix 4.

69 ADB. 2015. Completion Report: Third Road Upgrading (Sector) Project in the Republic of Fiji. Manila. 


\section{Summary of Risks and Issues, and Proposed Mitigating Actions and Improvements}

The table below summarizes the risk and issues in country financial management

systems that may affect project implementation. This list of risks and issues should guide project officers and mission leaders when designing financial management arrangements and conducting financial management and risk assessments.

\section{Common Issues, Problems, and Suggestions for Mitigating or Avoiding Risks}

Issues

Auditing Arrangement

The audited 2013 Whole of Government accounts revealed that the Office of the Auditor General (OAG) used the International Standards on Auditing. With the decision to change the accounting basis to Cash Basis International Public Sector Accounting Standards, the relevant auditing standard to be used should be that of the International Standards of Supreme Audit Institutions.

The $O A G$ and the internal audit and good governance Division of the MOE have started the implementation of the Teammate software, and as with all new software, this will need time for auditors to get used to, and may delay the assurance process required for ensuring the quality of the accounting records.

\section{Accounting and Reporting}

Staff turnover is a major issue in the island states, which complicates matters, given the lack of qualified and experienced auditors and accountants in both the OAG and the MOE.

The absence of bank reconciliations, as revealed by the audit of the 2013 accounts, casts doubt on the accuracy of the bank balances of overseas and domestic bank accounts, and consequently, the statement of financial position of government. This lack has resulted in overdrawn bank accounts and variances with the general ledgers.

The absence of accounts receivable reconciliations puts in question the reliability of the accounts receivable balance in the government's statement of financial position.

The government has changed its financial reporting from the calendar year to August-July commencing 2016. This will involve many adjustments in financial reporting, especially in terms of the preparation of the first year's accounts. The comparative year's accounts will take at least 2 years to be accurately determined.

\section{Recommended Solutions}

The Ministry of Economy (MOE) and OAG should develop an awareness and capacity development program for their staff so that they are well prepared for the auditing requirements when the change happens.

The MOE and OAG should strictly adopt the Teammate implementation program and ensure that necessary capacitybuilding programs are conducted so that there is a smooth transition.

The government should develop and employ various retention strategies such as private sector comparable remuneration packages to attract and retain qualified auditors and accountants.

The MOE should ensure that all bank reconciliations are completed monthly and on time, as this will facilitate the preparation of accurate bank balances at the end of the financial year.

The MOE should ensure that reconciliations of accounts receivable are completed monthly and on time.

The MOE should ensure that all necessary preparations for the change in the financial year are completed. 
Common Issues, Problems, and Suggestions for Mitigating or Avoiding Risks continued

\begin{tabular}{|c|c|}
\hline Issues & Recommended Solutions \\
\hline \multicolumn{2}{|l|}{ Legal Framework } \\
\hline $\begin{array}{l}\text { The inconsistencies between the } 2013 \text { Constitution, the } \\
\text { Financial Management Act 2004, and the Finance Instructions } \\
2010 \text { has not facilitated clear accountability and governance in } \\
\text { the management of public funds. While the Constitution has } \\
\text { delegated the role to chief executives, the Financial Management } \\
\text { Act } 2004 \text { and the Finance Instructions } 2010 \text { have yet to be } \\
\text { amended to make this clear. }\end{array}$ & $\begin{array}{l}\text { The government and MOE should make appropriate changes } \\
\text { in the Financial Management Act } 2004 \text { and the Finance } \\
\text { Instructions } 2010 \text { to ensure consistency with the Constitution } \\
\text { and provide clear accountability and governance arrangements } \\
\text { for public funds. }\end{array}$ \\
\hline $\begin{array}{l}\text { The independence of the OAG in tabling its reports in Parliament } \\
\text { (through the speaker) has affected the efficiency with which the } \\
\text { reports can be made public and scrutinized. The Constitution } \\
\text { provides for the tabling of reports in Parliament by the minister of } \\
\text { economy. }\end{array}$ & $\begin{array}{l}\text { The minister of economy should table in Parliament the } \\
\text { reports of the auditor general as and when these are produced. } \\
\text { Over the long term, appropriate legislative changes should be } \\
\text { considered, such as those authorizing the speaker to table the } \\
\text { reports outside the Parliament session to facilitate efficient } \\
\text { scrutiny of public finances. }\end{array}$ \\
\hline
\end{tabular}

\section{Planning and Budgeting}

The success of any project depends on the government's commitment, including the provision of counterpart funds. Any decision to change, reduce, or withdraw counterpart funds, especially those provided to mitigate the effects of natural disasters, will affect the planned program for the project.

Much effort has been made by the Strategic Planning Office, Ministry of Economy in the formulation of policies, effective implementation and monitoring of government initiatives, and implementation of government's medium to long-term development plans. However, government's political agenda may dictate and result in insufficient budgets for planned programs.

The project program should make allowances for such changes in counterpart funding to ensure that project implementation continues with minimal interruption.

The Strategic Planning Office, Ministry of Economy should regularly impress on the government the importance of implementing programs in accordance with timelines to achieve maximum benefits.

\section{Project Management}

In a period of high mobility of staff in the Pacific region, the project management unit may engage staff who may not be familiar with all the processes in project management, thus affecting project implementation.

The project management unit should ensure that appropriate training is provided to all staff implementing the project. 


\title{
Appendix 1 List of State Entities in Fiji
}

\author{
Government Commercial Companies (GCCs) \\ Airports Fiji \\ Fiji Broadcasting Corporation \\ Fiji Hardwood Corporation \\ Fiji Public Trustee Corporation \\ Food Processors (Fiji) \\ Post Fiji \\ Rewa Rice \\ Unit Trust of Fiji (Management) \\ Viti Corporation \\ Yaqara Pastoral Company

\section{Commercial Statutory Authorities (CSAs)} \\ Biosecurity Authority of Fiji \\ Fiji Electricity Authority \\ Fiji Meat Industry Board \\ Housing Authority \\ Maritime Safety Authority of Fiji \\ Public Rental Board \\ Water Authority of Fiji \\ Majority-Owned Companies (MOCs) \\ Air Terminal Services (Fiji) (51\%) \\ Copra Millers Fiji (96\%) \\ Fiji Airways (51\%) \\ Fiji Pine (99.8\%) \\ Fiji Sugar Corporation (68\%) \\ Pacific Fishing Company (98\%) \\ Minority-Owned Companies (MOCs) \\ Amalgamated Telecom Holdings (17.3\%) \\ Fiji Ports Corporation (41\%) \\ Off-Budget State Entity \\ Fiji Development Bank
}




\section{Appendix 2 \\ Fiji Institute of Accountants}

The membership of the Institute, except for those areas which are set out in section 8 of the Act, generally empowers the members whom it elects to the Council to Act on behalf of the membership (section 13 of the Act) and the Council is also granted specific powers under section 14 of the Act.

One of the powers granted to the Council is to make By-Laws, but it is important to note that such By-Laws must not cover areas that are reserved to the Institute under section 8, nor may any such By-Laws conflict with provisions of the Rules or Act.

The By-Laws currently prescribed by the Council are set out chronologically below:

\section{Standards By-Laws}

These early By-Laws, made in 1986, supersede similar ones made 10 years earlier, and give force to the Institute's obligation to encourage compliance by its members with the international standards set by IFAC and the IASB and make the failure to observe such standards a disciplinable offence.

\section{Continuing Professional Education By-Laws}

These By-Laws, introduced for the first time in January 2000, make it a requirement for members to undertake continuing professional education. The minimum number of CPE hours which members are currently required to complete is 30 hours of "structured" and 10 hours of "unstructured" education annually or 90 structured and 30 unstructured over a three year period.

\section{Code of Ethics}

The previous Fiji Code of Ethics was introduced in July 2000 and replaced the earlier Fiji Ethical Rulings. It was based on an earlier version of the IFAC Code of ethics and has now been replaced by the current IFAC Code, supplemented by provisions included in the previous Fiji Code but which are not included in the IFAC Code - listed as the Supplementary Code of Ethics. 


\section{Fees and Subscriptions By-Laws}

The admission and annual membership subscription rates, which were previously set out as an Appendix to the Rules, are, under Rule 7 (1) "as prescribed by the Council from time to time and approved by the Institute at an Annual General Meeting». The current rates are set out in the Fee Structure section of the Members section of the website.

\section{Fiji Accounting Standards}

The Fiji Institute of Accountants, which is a member body of the worldwide International Federation of Accountants, that is dedicated to achieving international Reporting Standards (now commonly referred to as "IFRSs") has adopted the IFRS standards for all accounting periods beginning from 1 January 2007 the IFRS for SME Standard was adopted and made effective for accounting periods beginning from 1 January 2011.

This will mean that the accounts for many organizations in Fiji need to be drawn up in accordance with the IFRS standards, which are, in many cases, different from the Fiji Accounting Standards used in the past.

The Fiji Accounting Standards continued to be used by entities that were not required to comply with the International Standards for accounting periods prior to 1 January 2011 but have now effectively been superseded.

The full IFRS standards will be applicable for all undertakings that fall within any of the following categories:

(i) Public companies, as defined in the Companies Act;

(ii) Government majority owned companies;

(iii) Banking and financial institutions;

(iv) Superannuation, insurance and insurance broking entities

(v) Government Entities established under their own statute with annual turnover of at least $\$ 5$ million

(vi) Entities who consistently over a period of 2 years comply with two out of the three following criteria:

(a) have recorded consolidated revenue for each of the financial years of more than $\$ 20$ million

(b) have recorded total assets as at the end of each of the financial years exceeding $\$ 20$ million

(c) have more than 50 employees of the parent and controlled entity at the end of each financial year

(vii) Entities that are publicly accountable with annual turnover of at least $\$ 5$ million (which have debt or equity instruments on public issue or have coercive power to tax, rate or levy to obtain public funds); and

(viii) Undertakings where any of the above listed entities have significant influence (through more than $20 \%$ ownership), provided turnover of such entities exceeds $\$ 5$ million, as equity accounting would be applicable for the parent company reporting. 


\section{Fiji Standards on Auditing}

A complete set of 37 Standards and Auditing Guidance Statements was brought into force for the audit of financial statements covering periods beginning in or after 1 January 2002. They were predominantly based upon the International Standards on Auditing issued by the International Federation of Accountants (IFAC) at that time. They have been replaced by the current set of audit related standards issued by IFAC with effect from 1 July 2008. 


\section{Appendix 3 \\ Diagrams of Financial Management Information System Modules}
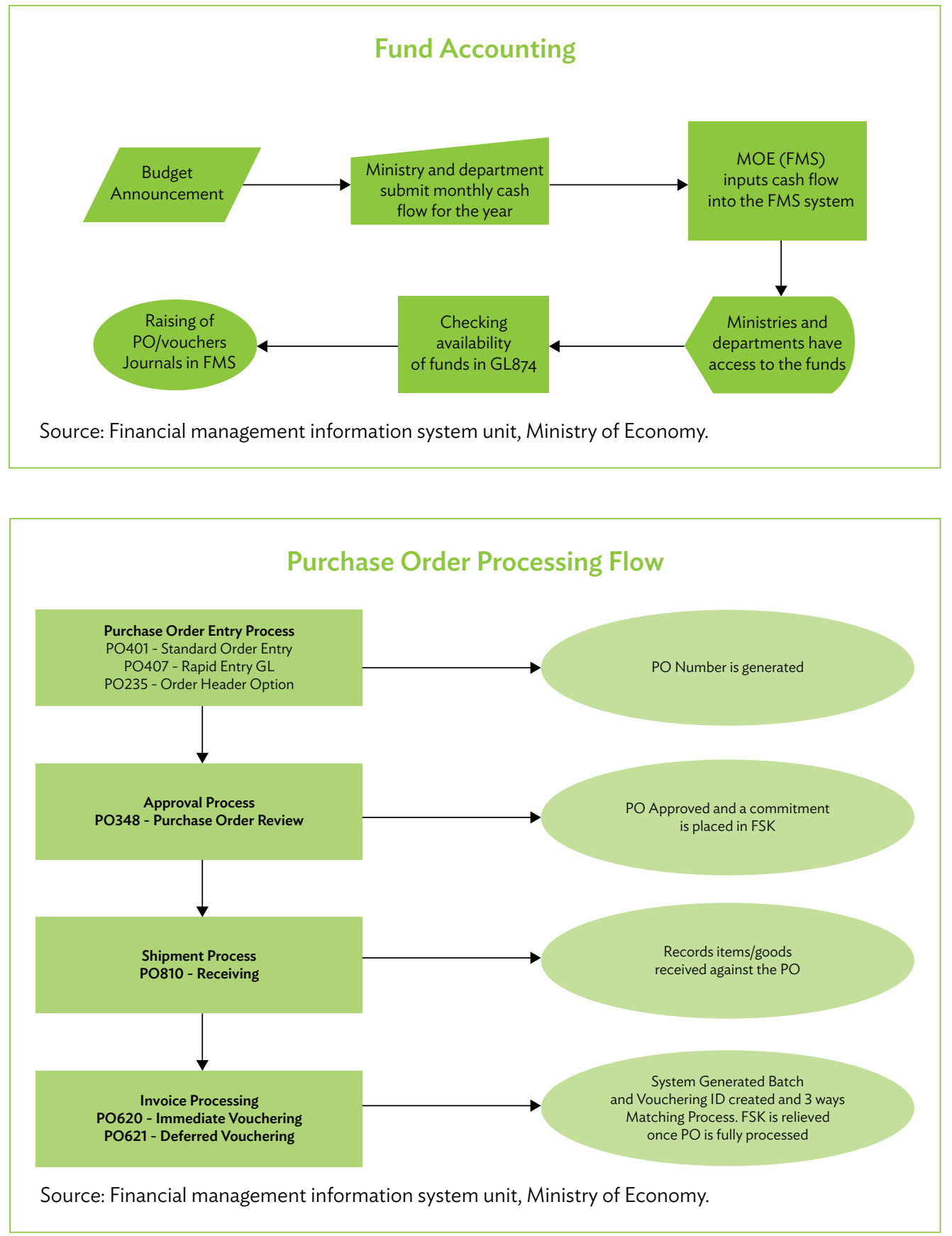

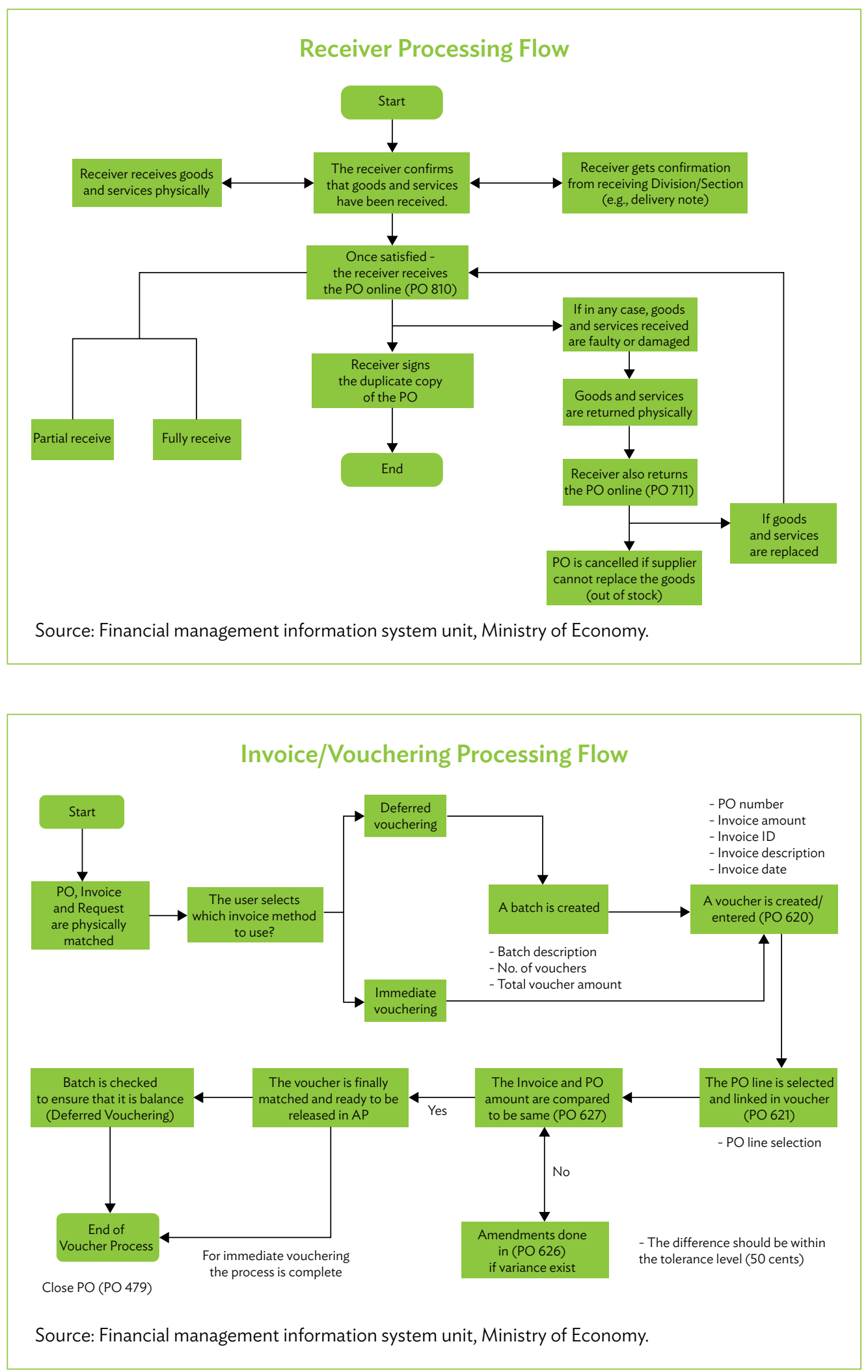


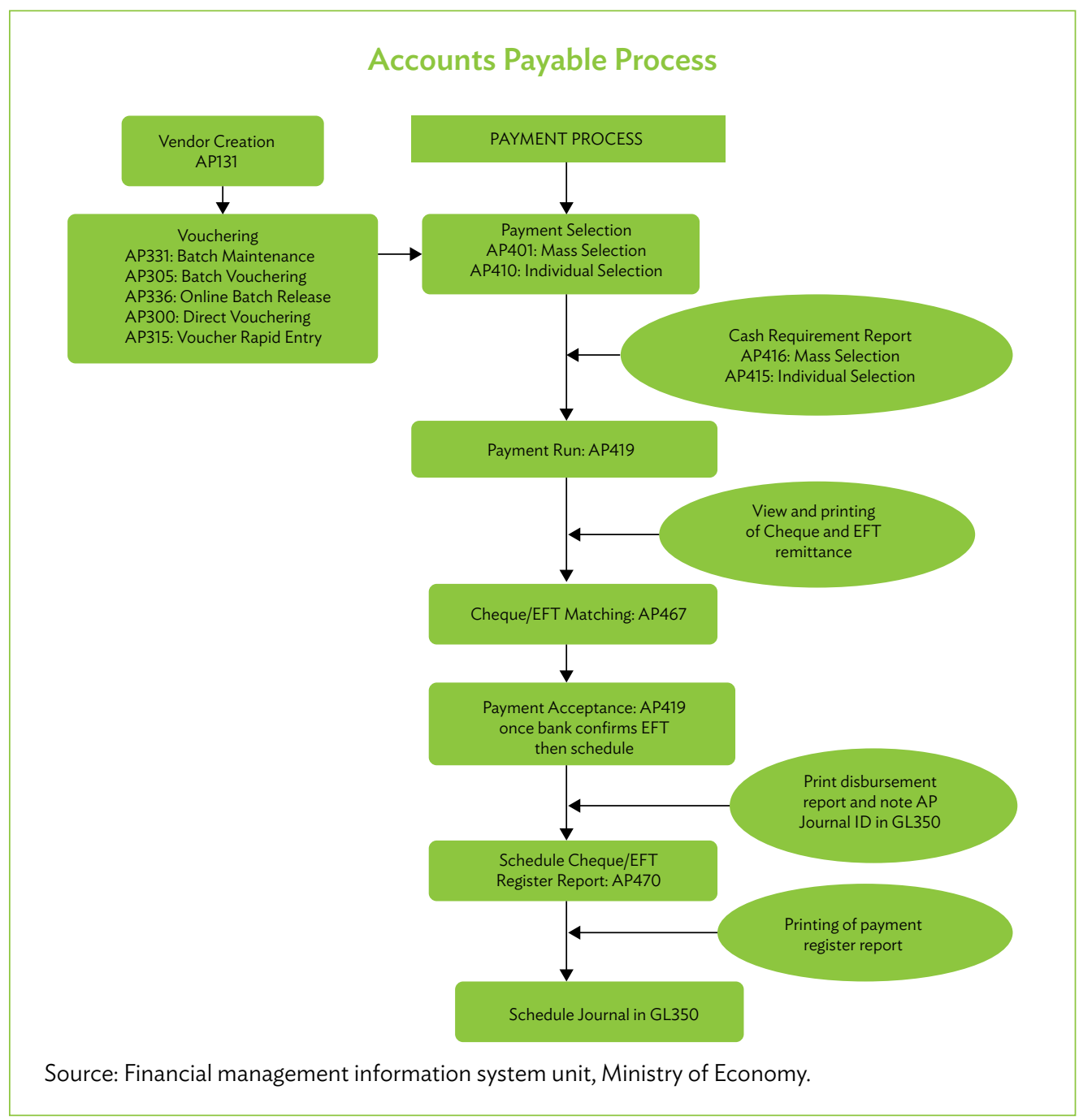




\section{Appendix 4 \\ Useful References and Suggested Readings}

\section{Fiji References}

Fiji Institute of Accountants. 1986. By-Laws. Suva.

Government of the Republic of Fiji. 2013. Constitution of the Republic of Fiji. Suva.

Government of the Republic of Fiji. 2014. Fiji Roads Authority: 2013 Annual Report. Suva.

Government of the Republic of Fiji. 2004. Financial Management Act 2004. Suva.

Government of the Republic of Fiji. 1996. Public Enterprise Act 1996. Suva.

Ministry of Economy.

Office of the Auditor General. 2013. Fiji Whole of Government Audited Accounts. Suva.

\section{ADB Guidelines and Documents}

ADB. 2015. Financial Management Assessment. Financial Management Technical Guidance Note. Manila.

ADB. 2015. Loan Disbursement Handbook. Manila.

\section{Other References}

Business Dictionary. Modified Accrual Basis Accounting. www.businessdictionary.com/ definition/modified-accrual-basis-accounting.html

International Auditing and Assurance Standards Board. The Clarified Standards.

Knowhow Nonprofit. The Basics of Financial Management. knowhownonprofit.org

World Bank. 2014. Debt Management Performance Asseessment (DeMPA): Fiji. Washington, DC.

World Bank. 2014. Debt Management Reform Plan: Fiji. Washington, DC. 


\section{Public Financial Management Systems-Fiji Key Elements from a Financial Management Perspective}

Fiji's financial reforms were disrupted by the coup of 2000. Since then, Fiji has initiated more targeted reforms. This report, for which work commenced in January 2016, documents the country's financial management systems covering budgeting, funds flow, accounting and reporting, and auditing systems. It provides insights into Fiji's internal control systems, staffing resource capacity, and information technology structure. The intent is to give project teams and consultants a better understanding of the country's financial management systems in order to improve project preparation. Find out how high-quality financial management assessments support projects by identifying key risks and enabling the implementation of appropriate actions and reforms to mitigate those risks.

\section{About the Asian Development Bank}

ADB's vision is an Asia and Pacific region free of poverty. Its mission is to help its developing member countries reduce poverty and improve the quality of life of their people. Despite the region's many successes, it remains home to a large share of the world's poor. ADB is committed to reducing poverty through inclusive economic growth, environmentally sustainable growth, and regional integration.

Based in Manila, ADB is owned by 67 members, including 48 from the region. Its main instruments for helping its developing member countries are policy dialogue, loans, equity investments, guarantees, grants, and technical assistance. 